\title{
La demolición de las puertas del recinto amurallado de León en los siglos XIX y XX. Una pérdida patrimonial irreparable
}

\author{
Emilio Morais ValLejo \\ Departamento de Patrimonio Artístico y Documental \\ Facultad de Filosofía y Letras \\ Universidad de León \\ emilio.morais@unileon.es
}

Recibido: 27-07-2012

Aceptado: 22-10-2012

\section{RESUMEN}

Durante la segunda mitad del siglo XIX y los primeros años del XX las autoridades municipales leonesas decidieron demoler las puertas históricas del recinto amurallado, liquidando de esta manera una parte importante del patrimonio de la ciudad. En el presente artículo analizamos y valoramos las razones y consecuencias de tal iniciativa, estudiando el proceso destructivo a partir de los datos obtenidos en los archivos. Gracias a esta labor investigadora hemos podido aclarar la mayoría de los hechos y las fechas en que ocurrieron, rebatiendo imprecisiones y ciertos errores publicados hasta el momento, al tiempo que contribuimos al establecimiento de una base documental para la comprensión de la historia patrimonial de las murallas de León.

Palabras clave: Puertas de la ciudad, murallas, arquitectura militar, conservación, patrimonio, León.

\section{The Demolition of the León City Wall Gates in the $19^{\text {th }}$ and Early $20^{\text {th }}$ Century: An Irreparable Loss of Heritage}

\begin{abstract}
In the second half of the nineteenth century and the early years of the twentieth, the municipal authorities of León took the decision to demolish the historical gates of the walled enclosure, thus destroying an important part of the city's heritage. In the present article, we will analyse and appraise the reasons and consequences of this initiative, studying this destructive process on the basis of information obtained from the archives. As a result of this research, we have been able to clarify most of the events and the dates on which they occurred, countering inaccuracies and some of the errors which have been published to date. At the same time, we have been able to contribute to the establishment of a documentary basis for understanding the historical heritage of the walls of León.
\end{abstract}

Key words: City gates, City Walls, Military Architecture, Conservation, Heritage, León.

Sumario: 1. Las puertas del recinto romano. 2. Las puertas de la Cerca Nueva. 
León fue desde el origen una ciudad fortificada, manteniendo su sistema defensivo más o menos vigente hasta la primera mitad del siglo XIX. El recinto amurallado se fue construyendo a lo largo de los siglos en diferentes etapas, hasta formar un amplio perímetro que ha llegado a nuestros días en un estado de conservación que permite comprender sin grandes esfuerzos la fortaleza y entidad que tuvo, o por qué se constituyó en emblema de la ciudad.

La primera muralla pétrea fue construida en el último cuarto del siglo I, cuando la Legio VII Gémina se asentó definitivamente en un altozano cerca de la confluencia de los ríos Bernesga y Torío ${ }^{1}$. El primitivo recinto romano se hizo siguiendo los esquemas tradicionales utilizados por el ejército imperial para sus campamentos, levantando los muros a base de pequeños y escuadrados sillares con la intención de que fueran consistentes y permanentes.

Durante la crisis bajo-imperial (s. III-IV), ante el miedo a un posible ataque, la muralla original fue reformada con el fin de proteger mejor y dar mayor apariencia de seguridad. Al muro primitivo se le adosó otro por la parte exterior, hasta alcanzar una anchura superior a los cinco metros y una altura entre ocho y diez metros, conformando un perímetro rectangular de aproximadamente 570 × 350 metros; además los lienzos fueron reforzados con unas 70 torres de planta semicircular peraltada. Esta obra es la que en gran parte ha llegado hasta nuestros días, aunque haya sufrido profundas reformas y lógicas alteraciones provocadas por la acción del tiempo y el efecto del paso de la historia ${ }^{2}$.

A partir del siglo XI la ciudad fue creciendo y desbordó el recinto romano, lo que obligó a la realización de una nueva barrera para proteger los arrabales de extramuros, conocida desde entonces como Cerca Nueva. Aunque sus principales misiones eran en principio resguardar y señalar un espacio definido por una jurisdicción urba$\mathrm{na}^{3}$, a mediados del siglo XIV tenía ya una estructura militar de gran envergadura al construirse una doble muralla de piedra ${ }^{4}$. Por la misma época, con el fin de completar

\footnotetext{
${ }^{1}$ Sobre la fundación de la ciudad véase, entre otros, GARCÍA BELLIDO, Antonio, Nueve estudios sobre la Legio VII Gemina y su campamento en León, León, 1968.

2 Sobre la muralla romana de León véase: AVELLO ÁLVAREZ, José Luis. "El ejército romano y el origen del urbanismo en la actual provincia de León", Actas del VIII Congreso Nacional de Historia del Arte, Mérida, t. II, 1993, p. 939-943; GARCÍA MARCOS, Victorino y VIDAL ENCINAS, Julio, “Asturica Augusta y Castra Legionis VII Geminae en la Asturia Cismontana", en Astures, Oviedo, 1995, pp.113-127; CAMPOMANES ALVAREDO, Emilio, "Nuevas perspectivas sobre el recinto amurallado romano de León", en Actas del Congreso Internacional Los orígenes de la ciudad en el noroeste hispánico, t. II, Lugo, 1996, pp. 1057-1076; GARCÍA MARCOS, Victorino y MORILLO CERDÁN, Ángel, "El campamento de la Legio VII Gemina en León. Novedades sobre su planta y sistema defensivo", Lancia, no 4, 2001, pp. 103-126; MORILLO CERDÁN, Ángel y GARCÍA MARCOS, Victorino, "Legio VII Gemina and its Flavian fortress at León", Journal of roman archaeology, $n^{\circ}$ 16, 2003, pp. 275-286; GARCÍA MARCOS, Victorino, "Los campamentos de las legiones VI victrix y VII gemina en León, en Arqueología militar romana en Europa, Madrid, 2005, p. 167-195.

3 VALDEÓN BARUQUE, Julio, "Reflexiones sobre las murallas urbanas de la Castilla medieval", en La ciudad y las murallas, Madrid, 1991, p. 79.

${ }^{4}$ Sobre la Cerca Nueva véase, QUADRADO, José María, Recuerdos y bellezas de España. Asturias y León, Madrid, 1855, p. 368; REPRESA, Armando, "Evolución urbana de León en los siglos XI-XIII", Archivos Leoneses, 45-46, 1969, pp. 253-262; ESTEPA DÍEZ, Carlos, Estructura social de la ciudad de León (s. XI-XIII), León, 1977, p. 124-142; GONZÁLEZ GALLEGO, Isidoro, "Las murallas y los puentes de León en el siglo XIV", León y su historia, t. IV, León, 1977, pp. 367-404; BENITO RUANO, Eloy, "Las murallas y cercas de la ciudad de León durante la Edad Media", León medieval. Doce Estudios, León, 1978, pp. 2540; MATEO MARCOS, Juan, Origen, evolución y decadencia del recinto amurallado de León, León, 1981; ÁL-
} 
la defensa de la ciudad, se terminó de definir el Castillo de la ciudad, ubicado al lado de la puerta septentrional $1^{5}$.

$\mathrm{Al}$ unirse las dos murallas, la romana y la medieval, se completó un vasto perímetro amurallado de casi tres kilómetros de longitud sin cortes ni vacíos, aunque formado por dos tipologías distintas, respondiendo cada una de ellas a las características propias de la época en que fue construida. Debido a su importante valor patrimonial fueron declaradas Monumento Nacional por Decreto de 3 de junio de $1931^{6}$.

A principios del siglo XIX el recinto mantenía un estado de conservación aceptable, gracias a la solidez de los muros y los arreglos realizados a lo largo de su existencia. Aunque su valor defensivo había quedado obsoleto debido a las nuevas armas artilleras y los cambios en la poliorcética, la Guerra Carlista volvió a dar vigencia a las murallas leonesas. Entonces, para actualizar la defensa de la ciudad, se procedió a la reconstrucción de las partes caídas de los muros, erección de nuevas estructuras o fortificación de la mayoría de las puertas, algunas de las cuales fueron cegadas para favorecer el aislamiento de la ciudad ante el enemigo ${ }^{7}$.

La muralla perdió sus principales funciones al poco tiempo de finalizado el conflicto dinástico, así como disminuyó el significado ganado durante siglos, convirtiéndose en una imagen exánime de lo que había sido en otras épocas ${ }^{8}$. En esta circunstancia, es fácil de comprender que las puertas son lo primero que estorba y lo que antes se quería suprimir, según apremiaba el urbanismo decimonónico que se extendía por toda Europa. Queremos recordar aquí que las puertas sirven para franquear o clausurar un espacio; también las de las ciudades, y por eso tenían un horario de apertura y cierre. Sabemos que en esa época de peligro los accesos que tenían tránsito se clausuraban por la noche. En efecto, el 9 de abril de 1839, cuando la posibilidad de un ataque parecía más alejada, una orden de la autoridad militar relajó un poco el horario, disponiendo que desde ese día las puertas de la ciudad se cerrasen a las ocho, en vez de a las siete como hasta entonces, y los postigos a las diez en lugar de a las nueve?.

La última referencia que tenemos de todas las puertas de la ciudad en pie, nos la proporciona el Plano de la magistral del recinto fortificado de León ${ }^{10}$, realizado por Teodoro Otermín en 1839 con motivo de la Guerra Carlista (fig. 1). En él comprobamos el trazado continuo del extenso perímetro amurallado, de manera que abrazaba la ciudad sin interrupción. En el dibujo están señaladas todas las puertas, apuntando

VAREZ ÁLVAREZ, César, La ciudad de León en la baja Edad Media. El espacio urbano, León, 1992, pp. 41-63; GUTIÉRREZ, José Avelino y MIGUEL, Fernando, "Génesis del urbanismo en la ciudad de León y su transformación en la Edad Media", Codex Aquilarensis, n 15, 1999, pp. 43-90.

5 Una aproximación a la historia y significado del Castillo se trata en, MORAIS VALLEJO, Emilio, "El Castillo de León. Breve historia de un valor patrimonial", De Arte, no 4, 2005, pp. 135-160.

6 RIVERA BLANCO, Javier, (coord.), Catálogo monumental de Castilla y León. Bienes inmuebles declarados, Salamanca, 1995, pp. 327-328.

7 Sobre estos trabajos, véase MORAIS VALLEJO, Emilio, "La muralla de León en el siglo XIX: última misión militar y su repercusión en el patrimonio arquitectónico", BSSA arte, LXXVII, 2011, pp. 227-252.

8 A este proceso se le conoce como "la irreversible crisis de las murallas en el siglo XIX". Cf. SETA, Cesare de, "Las murallas, símbolo de la ciudad", en La ciudad y las murallas, Madrid, 1991, p. 64.

9 Archivo Histórico Municipal de León (desde aquí, AHML), caja $716, \mathrm{n}^{\circ} \mathrm{1}, \mathrm{s} / \mathrm{f}$.

10 OTERMÍN, Teodoro, Plano que representa la magistral del recinto fortificado de la Ciudad de León, Centro Geográfico del Ejército, Archivo Cartográfico y de Estudios Geográficos, arm. E, Tabla 7, Carp. 1 ${ }^{\mathrm{a}}, \mathrm{n}^{\mathrm{o}}$ 305 . 


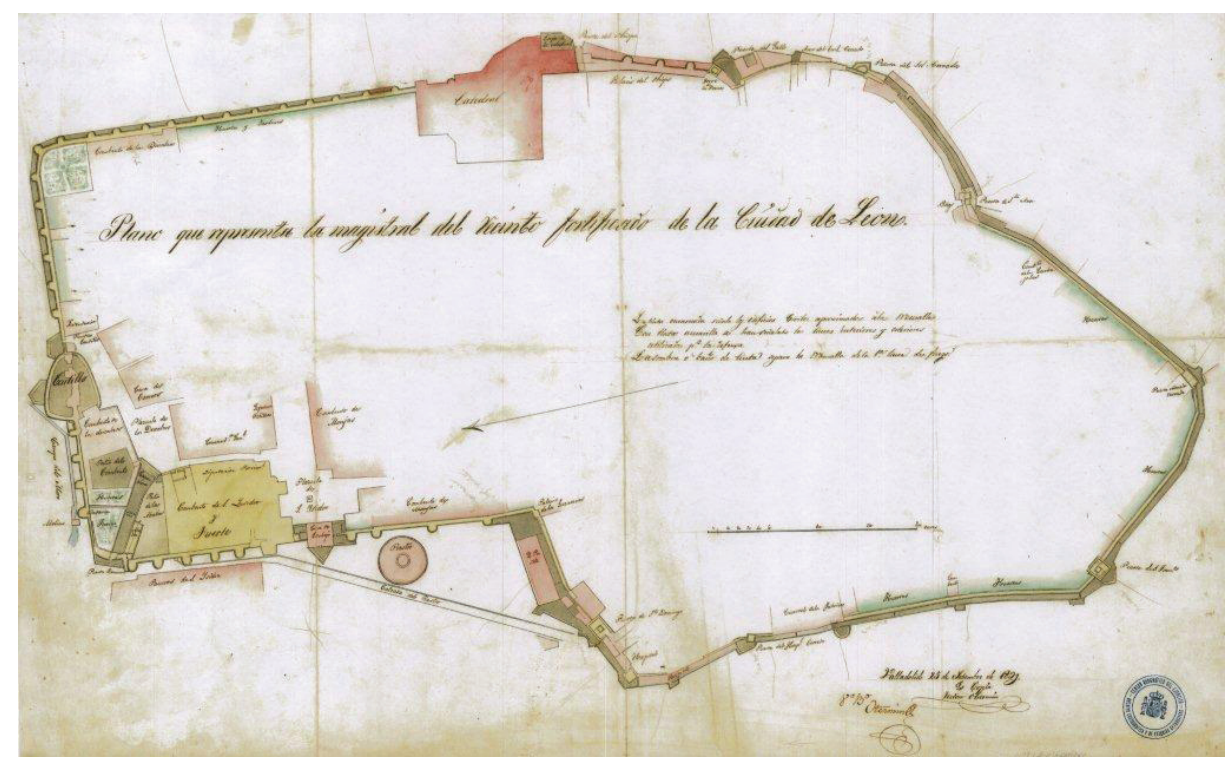

Fig. 1: Plano de la línea magistral del recinto amurallado de León. Teodoro Otermín, 1839.

el nombre por el que eran conocidas entonces y con una somera configuración de la planta. También constatamos que, debido a los peligros inherentes a la guerra, la mayoría fueron cerradas a cal y canto, mientras que las demás fueron reforzadas con defensas exteriores y obras nuevas con el fin de controlar mejor el paso a través de ellas o defender el puesto con solvencia en caso de ataque enemigo.

No sería hasta octubre de 1840 cuando, a petición del Ayuntamiento y con el fin de facilitar la comunicación de los barrios extramuros con el centro del casco urbano, el Comandante General de la Zona consideró oportuno practicar más entradas, ordenando la apertura de Puerta Sol y Puerta Moneda, realizando en ellas diversas obras de fábrica y carpintería para ponerlas activas en las mejores condiciones posibles ${ }^{11}$. La idea era hacer la ciudad más permeable en un momento en el que la región parecía pacificada, pero manteniendo todavía ciertos elementos defensivos, y además con la condición de su reversibilidad por si fuera necesario volver a cerrarlas en un futuro ${ }^{12}$.

Así pues, la decadencia definitiva de las murallas de León comienza una vez terminada la Guerra Carlista. Hasta ese momento habían sido consideraras útiles, cumpliendo a lo largo de los siglos variadas funciones que iban desde las militares, sociales y políticas, hasta las económicas, sin olvidar las implicaciones jurídicas, simbólicas e ideológicas ${ }^{13}$. Pero poco a poco la mayoría de ellas fueron perdiendo su sentido, por lo que se hicieron vulnerables.

11 La autorización de las obras fue firmada por el Comandante General de la plaza el 23 de octubre de 1840, según recoge el correspondiente documento, cfr. AHML, caja 716, nº 1, s/f.

12 Los trabajos para adecuar ambas puertas fueron proyectados por el arquitecto Perfecto Sánchez Ibáñez. Cfr. AHML, caja $716, n^{\circ} 4, \mathrm{~s} / \mathrm{f}$.

13 Le GOFF, Jacques, "Construcción y destrucción de la ciudad amurallada. Una aproximación a la reflexión y a la investigación”, en La ciudad y las murallas, Madrid, 1991, p. 11. 
En un sistema inicialmente militar, las puertas son piezas muy importantes, no sólo por su carácter defensivo o porque cierran y abren el espacio urbano al exterior, sino también por ser un elemento de primer orden para el control de los flujos de personas y mercancías. No obstante, su condición cambia a mediados del siglo XIX, como sucedió en otros muchos lugares de España a semejanza del resto de Europa, debido al crecimiento extramuros de la población y la planificación de los ensanches. Esta idea conllevaba asociada la demolición de partes importantes de la muralla y el derribo de la mayoría de las puertas, cuestión que se consideraba del todo necesaria con objeto de liberar espacios para dar paso a nuevas calles y modernos edificios, olvidando los méritos históricos y la consideración patrimonial de las antiguas construcciones ${ }^{14}$. Las murallas, cuidadas durante siglos para mantenerlas operativas, perdieron la impronta de utilidad defensiva que había sido su razón de ser hasta entonces, pasando a considerarse un obstáculo muy incómodo para el periodo de paz y de expansión económica que se presumía, ya que su permanencia dificultaba el desarrollo y conexión de los diferentes tejidos urbanos ${ }^{15}$. Cuando un bien patrimonial deja de tener la utilidad primigenia y no se le asigna otra en sustitución, es fácil predecir que su desaparición es cosa de poco tiempo; por eso las operaciones urbanísticas decimonónicas trataron de justificar la incompatibilidad de los recintos fortificados con el nuevo orden funcional que se pretendía establecer en las ciudades burguesas, planificadas con parámetros diferentes a los utilizados hasta el momento ${ }^{16}$.

La ciudad de León no fue ajena a esta corriente y también quiso modernizarse. Alrededor del año 1850 cristaliza un estado de opinión contrario al mantenimiento de las puertas, que son calificadas mayoritariamente como una barrera urbana sin ningún valor (obviando incluso el patrimonial o el histórico), considerándolas deterioradas y viejas (que no antiguas), y por lo tanto destinadas a la piqueta. A todo esto se unía el deseo de abrir las entradas que habían sido clausuradas durante años con motivo de la Guerra Carlista, lo cual había ocasionado indudables incomodidades a los ciudadanos. En este sentido la primera petición formal la hizo el duque de Frías, quien solicitó la apertura del postigo del Rastro, próximo al renacentista palacio de los Guzmanes, una vez acabado el conflicto ${ }^{17}$. El Ayuntamiento, atendiendo los intereses de la población, decidió franquear el paso en diciembre de $1850^{18}$, aprobando además el derribo de una parte de la muralla contigua ${ }^{19}$. Poco después, en julio de 1851, la corporación municipal aprobó el derribo de la puerta conocida como Arco de Ánimas, por considerar que estaba en estado ruinoso ${ }^{20}$. Estas dos decisiones fueron

\footnotetext{
14 El derribo de las murallas, o parte de ellas, fue un proceso generalizado en España, levantando interesantes polémicas, véase MAS HERNÁNDEZ, Rafael, La presencia militar en las ciudades, Madrid, 2003, p 165 y ss.

15 RAMOS GUALLART, Javier, "La batalla en las murallas. León, siglos XIX y XX”, en La ciudad y sus murallas, Granada, 1996. p. 228.

16 Un caso similar en TEIJEIRA, Ma Dolores, "La conservación de un patrimonio en desuso. Actuaciones en las murallas de Zamora durante el siglo XX", Espacio, Tiempo y Forma, Serie VII, H ${ }^{a}$ del Arte, t. 22-23, 2010, pp. 217-233.

17 AHML, caja 93, n 141, fol. 83 r.

18 AHML, caja 93, nº 141, fol. $102 \mathrm{v}$.

19 Se aprovechó la ocasión para proyectar el derribo de la muralla que existía entre el palacio de los Guzmanes y el convento aledaño de las monjas recoletas, AHML, caja 93, nº 142, fols. 42 y 43 r.

20 AHML, caja 93, n 142 , fol. 44 r y v.
} 
el origen de un rápido movimiento destructor que afectó en poco tiempo al resto de las puertas, que fueron desapareciendo una tras otra de forma acelerada e implacable. No hay constancia documental de que hubiera un plan oficial para acabar con ellas, pero, aunque no fuera explícito, podemos afirmar que estaba claramente en el ánimo de la clase dirigente de la ciudad leonesa. Entre 1851 y 1856 el Ayuntamiento aprobó el derribo de cinco puertas medievales (Ánimas, San Francisco, Santa Ana, Peso de la Harina, Santo Domingo), otras dos más entre 1864 y 1868 (Sol y Moneda), hasta culminar el proceso con la demolición en 1910 de Puerta Obispo, la que más tiempo resistió porque era la más monumental, pero sobre todo porque permanecía oculta en terreno catedralicio. Se encadenaron entonces una serie de circunstancias que resultaron ser definitivas para su extinción, lógicamente relacionadas con la inexorable decadencia de las murallas en su conjunto. La cuestión llega hasta nuestros días, aunque ahora las instituciones tienen el deseo de revitalizarlas, atendiendo a su indudable valor patrimonial ${ }^{21}$.

En el año 1833, bajo la regencia de María Cristina, se formalizó la actual división provincial de España diseñada por Javier de Burgos, constituyéndose entonces León en capital de provincia ${ }^{22}$, resolución que fue utilizada como pretexto para iniciar un cambio de imagen de la ciudad. Por otro lado, entre 1852 y 1860 se prodiga la regulación urbanística con el inicio de las primeras experiencias de intervención urbana ${ }^{23}$, siendo una actuación recurrente la alineación de las viejas y tortuosas calles históricas, actuación que en aquellos momentos era considerada como una prueba de modernidad propia de las principales ciudades. Madrid hizo públicas en 1853 las Bases sobre alineación de calles, estableciendo un criterio que ejerció una fuerte influencia en toda España, ya que no debemos obviar el efecto mimético que provocan ciertas actuaciones de las capitales más importantes ${ }^{24}$. También León se apuntó a la corriente renovadora y se presentaron por esas fechas varios proyectos de alineación ${ }^{25}$, que en ocasiones entraban en conflicto con las murallas y las puertas. De hecho, el Ayuntamiento acometió la realización de un plano actualizado de la ciudad, con la intención de que sirviera de base para proyectar las necesarias modificaciones urbanas y establecer nuevas disposiciones viarias acordes con el modelo de ciudad moderna que se pretendía conseguir. El resultado fue el célebre plano de Joaquín Pérez Rozas ${ }^{26}$, levantado en 1862 y actualizado para su publicación en 1889 por J. M. Ruiz de Salazar, documento indispensable para el conocimiento urbanístico de la ciudad leonesa decimonónica ${ }^{27}$.

21 Existe un Plan Director de la Muralla de León desde el año 2009.

22 Gaceta de Madrid, $\mathrm{n}^{\circ}$ 154, 3 de diciembre de 1833. El Real Decreto establece en su Artículo $1^{\circ}$ El territorio español en la Península é islas adyacentes queda desde ahora dividido en 49 provincias.

23 REGUERA RODRÍGUEZ, Antonio, La tesis de las tres ciudades. Principios y prácticas de la planificación urbana estatal y su aplicación a la ciudad de León, León, 2004, p. 55.

24 Sobre este tema véase, BASSOLS COMA, Martín, Génesis y evolución del Derecho Urbanístico español, Madrid, 1973, pp. 104 y ss.

25 REGUERA RODRÍGUEZ, Antonio, La ciudad de León en el siglo XIX, León, 1987, pp. 111-162.

26 AHML, caja 95, nº 148, fol. 10.

27 Sobre actuación urbanística de León en esta época, véase, REGUERA RODRÍGUEZ, Antonio, (2004), op. cit. 
También constatamos el progresivo aumento de la población y cierta mejora económica, lo cual provocaba un tráfico más denso en las vías públicas, que necesitaba calles más anchas y rectas. Esta novedad era considerada inconciliable con la estrechez de las puertas históricas, que se convertían así en una traba para el crecimiento y renovación de la urbe, además de dificultar la comunicación con los barrios extramuros. Por otro lado, tenemos que anotar que se produce entonces la llegada del ferrocarril a León, ubicándose la estación en una zona alejada del centro, al otro lado del río, por lo que fue necesario trazar una amplia calle (actual Ordoño II) para establecer una buena y rápida comunicación con el casco histórico, teniendo que atravesar para ello de manera ineludible la vieja muralla en la zona de Santo Domingo.

Una particularidad común a la época era la preocupación de las corporaciones municipales por la higiene urbana, la comodidad de los ciudadanos y la economía de la población ${ }^{28}$. Son muchas las ocasiones en las que vemos como recurren a estos motivos para justificar demoliciones de edificios, adecentar zonas degradadas, hacer nuevos trazados sobre las calles antiguas o solicitar derribos de partes del recinto fortificado. Sirva de ejemplo la argumentación con la que el Ayuntamiento justificó el derribo de parte de la muralla en la calle de Santa Cruz en 1865:

Hallándose recomendado en la recopilación de medidas higiénicas publicada por el Gobierno, que desaparezcan todos los obstáculos que se opongan a la ventilación de la población, y siendo notorio que el bastión de muralla que se encuadra a la entrada de la calle de Santa Cruz, dificulta la circulación del aire en aquella parte baja y de población apiñada, y hasta es un inconveniente para la viabilidad, se acuerda que se proceda a su inmediato derribo, formado que sea el presupuesto por el Arquitecto ${ }^{29}$.

En cuanto a cuestiones económicas, una de las medidas que influyó para acelerar la apertura total de las murallas fue el Decreto que firmó en 1843 el ministro de Hacienda, Juan Álvarez y Mendizábal, por el cual quedaban suprimidos los “derechos de puertas de las ciudades" que algunas capitales de provincia exigían hasta entonces a ciertos productos que entraban en ellas ${ }^{30}$. Otro motivo más para considerar obsoleta la existencia material de las puertas y dar nuevos argumentos a los partidarios de su desaparición, con la evidencia de la pérdida total de funcionalidad.

Dentro del deseo de modernización de la ciudad se hizo un plan de mejora de las principales vías urbanas, no solo con el diseño de nuevos trazados sino también con obras destinadas a pavimentar las viejas calles (hasta entonces de tierra en su mayoría), maltratadas por el tiempo y poco adecuadas para el aumento que iba a experimentar la circulación de vehículos en la nueva etapa. Para llevar a cabo tamaña empresa había poco dinero en las arcas municipales, por eso hubo que recurrir a tipos de financiación poco habituales y utilizar recursos de toda índole para abaratar costes. Entre estos estaba el aprovechamiento de los materiales procedentes del derribo de

28 MAS HERNÁNDEZ, Rafael, (2003), op. cit., p 166.

29 AHML, caja 95, $\mathrm{n}^{\circ} 150$, fol. $43 \mathrm{r}$.

30 Gaceta de Madrid, n 3.153, $26-\mathrm{V}$ - 1843. Artículo 1: "Quedan suprimidos desde $1^{\circ}$ de junio próximo los derechos de puertas que con aplicación a la Hacienda pública se están exigiendo en 28 capitales de provincia..." 
las murallas, de manera que muros históricos sirvieron para hacer el firme de varias calles leonesas, como contaremos más adelante. Visto de esta manera, la desaparición de las puertas servía también para este objetivo.

Por otro lado, algunos vecinos querían que se hiciera efectiva la desaparición de muros, puertas y baluartes con la intención emplear el espacio resultante en la construcción de nuevos edificios o la ampliación de los existentes, aprovechando un momento en el que se preveía un aumento de la demanda de viviendas al socaire del intuido desarrollo económico del país. Así, veremos cómo fueron habituales las solicitudes al Ayuntamiento para ocupar la parte liberada por el desmantelamiento de las antiguas estructuras militares.

A todo ello se uniría más tarde la planificación del Ensanche de León y la consiguiente urbanización de los terrenos inmediatos a la muralla ${ }^{31}$. Coincide en el tiempo con una corriente urbanizadora generalizada en toda España, lo que originó la urgente necesidad de promulgar una legislación a nivel estatal para regularizar los crecimientos urbanísticos planificados ${ }^{32}$.

Las demoliciones no encontraron prácticamente oposición; ni intelectuales o grupos de opinión, ni instituciones o ciudadanos manifestaron mayor interés por salir en defensa de las puertas con valor histórico o artístico. Solo en contadas ocasiones vemos actuar a la Comisión de Monumentos, pero con escasa efectividad; prueba palpable de lo poco arraigado que estaba el sentimiento de conservación del patrimonio en aquellas fechas y la ausencia de leyes para la defensa de monumentos. El Gobernador era la autoridad que tenía algún poder para actuar, y en alguna ocasión logró dilatar demoliciones, unas veces por defectos de forma en la actuación administrativa, otras por falta de permisos oficiales y las menos por considerar que no estaban garantizados los derechos individuales de algunos propietarios, pero nunca por un criterio artístico o patrimonial; en cualquier caso, constatamos que no impidió la desaparición de ninguna puerta. Tampoco la Diputación, a pesar de ser una instancia superior la que tenía que aprobar en último término las demoliciones, puso mayores inconvenientes, y en las pocas ocasiones en las que encontró razones para oponerse, finalmente acabó cediendo.

En cuanto a los particulares, sólo les vemos protestar cuando la destrucción afecta a sus propiedades o intereses personales, nunca por la pérdida de un valor histórico o artístico. Analizando la documentación hemos comprobado que algunos ciudadanos se opusieron a la desaparición de las puertas, pero porque sus viviendas estaban apoyadas en los machones de los arcos de acceso y su desaparición afectaría a la estabilidad de sus casas. Incluso algunos alegaban que en su momento compraron al Estado parte de la muralla, iniciándose litigios que siempre ganaba fácilmente el Ayuntamiento porque argumentaba que la muralla no podía en ningún caso ser patri-

31 El proyecto definitivo de Ensanche de León se presentó en 1897 y fue aprobado en 1904, véase, CORTIZO ÁLVAREZ, Tomás, "El Ensanche de León. Proyecto y primera ocupación", en Los Ensanches en el urbanismo español. El caso de León, Madrid, 1999, p. 88.

32 Cfr. Ley de Ensanche de 1864, Ley de Ensanche de 1876, Ley de Ensanche de 1892, Ley de Saneamiento y mejora interior de las poblaciones de 1895. Sobre el tema se puede consultar LORA-TAMAYO VALLVÉ, Marta, Historia de la Legislación Urbanística, Madrid, 2007. 
monio particular, pues su propiedad es de índole imprescriptible y la concesión del permiso de uso no puede llevar aparejado derechos permanentes ${ }^{33}$.

Teniendo en cuenta todo este cúmulo de episodios, es fácil comprender que las puertas de la muralla leonesa no fueran vistas en aquella época como bienes patrimoniales dignos de conservación. Al contrario, fueron consideradas mayoritariamente un obstáculo para el objetivo de modernización de la ciudad y una incomodidad para los vecinos, pasando a contemplarse como unas viejas edificaciones sin utilidad que era mejor suprimir cuanto antes. Ayudaba a todo esto la falta de conciencia ciudadana y el escaso interés por el patrimonio cultural que había en aquella época, aprovechado todo ello por políticos y constructores para mover la opinión pública hacia sus intereses, siendo paradigmática en este sentido la campaña periodística que se organizó para forzar la demolición de Puerta Obispo ${ }^{34}$.

Comienza así el irreversible y rápido proceso de destrucción, propiciado además porque prácticamente no existía una legislación para la protección y conservación de los bienes artísticos o culturales. Casi la única normativa vigente era la poco definida Real Cédula de Carlos IV aprobada en 1803, Instrucciones sobre el modo de conservar y recoger los monumentos antiguos que se descubran en el Reyno, baxo la inspección de la Real Academia de la Historia, cuyo preámbulo expone como principal objetivo poner a cubierto las antigüedades que se descubren en la Península de la ignorancia que suele destruirlas, que, como veremos, fue poco efectiva en este caso $^{35}$. En el año 1844 se promulgó una Real Orden que creaba las Comisiones de Monumentos Históricos y Artísticos, con la idea de evitar la destrucción o pérdida de los monumentos de interés, lo que supuso un tímido comienzo de la protección del patrimonio monumental español, aprobándose su reglamento en $1865^{36}$. La Comisión Provincial de León no se caracterizó precisamente por intervenir de manera activa en la conservación de los elementos patrimoniales, pero tampoco por su labor en la regulación del proceso demoledor para mitigar las pérdidas, al menos eso es lo que se desprende de la documentación conocida hasta el momento. En cualquier caso, tenemos que destacar que es el propio Ayuntamiento de León quien lleva el protagonismo de la acción destructiva, siendo en la práctica totalidad de las causas quien promueve los desmontes, incluso en contra de los vecinos que protestan por verse negativamente

33 Así se recoge, como ejemplo característico, la disputa entre el Ayuntamiento y el ciudadano Francisco Valle Soriano generada a raíz del desmonte del baluarte de Santa Ana en 1866, cfr. AHML, caja 95, $\mathrm{n}^{\circ}$ 150, fol. 7 .

34 Fueron protagonistas en esta campaña periódicos locales como el Diario de León o El Porvenir de León, pero también se hizo eco la prensa nacional como La Correspondencia de España. Parte de la polémica se recoge en PONGA MAYO, Juan Carlos, León perdido, León, 2009, pp. 36-40.

35 Sobre la Real Cédula tratan CALAMA, José María y GRACIANI, Amparo, La restauración decimonónica en España, Sevilla, 1998, p. 29; MUÑOZ COSME, Alfonso, La conservación del patrimonio arquitectónico español, Madrid, 1989, p. 27; MAIER ALLENDE, Jorge, "II Centenario de la Real Cédula de 1803. La Real Academia de la Historia y el inicio de la legislación sobre el Patrimonio Arqueológico y Monumental de España", Boletín de la Real Academia de la Historia, no 200, 2003, pp. 439-473.

36 Sobre las Comisiones de Monumentos, véase, ORDIERES DÍEZ, Isabel, Historia de la Restauración monumental en España, Madrid, 1995, pp. 46-64; CALAMA, José María y GRACIANI, Amparo, (1998), op.cit., pp. 33-34; MACARRÓN, Ana, Conservación del Patrimonio Cultural. Criterios y normativas, Madrid, 2008, pp. 181-182. 
afectados y piden indemnizaciones por los estragos cometidos en los edificios anejos debido a la mala práctica en las demoliciones.

Si conservamos una parte importante de las murallas leonesas se debe en gran medida a los edificios, unos civiles y otros religiosos, que durante siglos se apoyaron en ellas, tanto por el exterior como por el interior del recinto. De esta manera, la fiebre destructora de las murallas no afectó en León de manera tan grave como en otras localidades, pues su derribo llevaba implícito el desmoronamiento de aquellos edificios. Las puertas no tuvieron tanta suerte y desaparecieron todas, salvándose únicamente Puerta Castillo, que fue levantada en el siglo XVIII. Bajo tierra subsisten cimientos de algunas, que salen a la luz en las excavaciones arqueológicas, y otros pocos vestigios podemos rastrear en aquellas casas que aprovecharon sus estructuras para erigirse y siguen en pie. A la pérdida del patrimonio material se une la ausencia de todo tipo de imágenes, lo que impide conocer la fisonomía que tuvieron. Excepto Puerta Obispo, fotografiada y descrita justo en el momento de su destrucción, de las demás (y no de todas) solo tenemos imágenes de su ruina, pero no de cuando estaban completas; tampoco disponemos de descripciones literarias o técnicas, salvo algún dato transversal e inconcreto, para hacernos una idea de su configuración. En planos urbanos de la época hemos localizado el dibujo esquemático de la planta de algunas de ellas, pero esto es notoriamente insuficiente para reconstruir su apariencia. Así, solo nos queda la opción de recurrir a la deducción y a la comparación con estructuras similares para suponer cómo pudieron ser las puertas de la muralla de León que perdimos.

A la hora de aprobar los derribos, en la mayoría de los expedientes se arguye que las estructuras están en mal estado o simplemente ruinosas. Pero la argumentación es difícil de explicar cuando hacía poco tiempo, con motivo de la Guerra Carlista, se había renovado y reforzado la muralla, concediendo además especial atención a las puertas. Todo parece indicar que triunfa el grito ¡Abajo las murallas! que esgrimía el nuevo orden urbano burgués ${ }^{37}$, en aras de facilitar operaciones que satisfacían sus intereses, aunque fuera en contra de la conservación del patrimonio común ${ }^{38}$. Paradójicamente, la mayor batalla que libraron las murallas leonesas sucedió en tiempos de paz $^{39}, \ldots$ también su mayor derrota.

A continuación analizamos el proceso destructivo de las puertas históricas, centrado entre 1850 y 1910 , teniendo como base la documentación obtenida en la investigación de archivos. Gracias a los datos obtenidos podemos fechar la mayoría de los derribos así como clarificar hechos y circunstancias, puntualizando las pocas noticias publicadas hasta el momento sobre el tema, en ocasiones erróneas y muchas veces $\sin$ apoyo documental (fig. 2).

37 ¡A Abajo las murallas!, es el título del trabajo del médico e higienista Monlau que ganó el concurso convocado en 1841 por Ayuntamiento de Barcelona con el fin de aportar ideas para la renovación urbana de la ciudad.

38 ISAC, Ángel, "Ciudad cerrada y ciudad abierta. La muralla en la historia de la ciudad”, en La ciudady sus murallas. Conservación y restauración, Granada 1996, p. 81.

39 RAMOS GUALLART, Javier, (1996), op. cit, p. 223. 


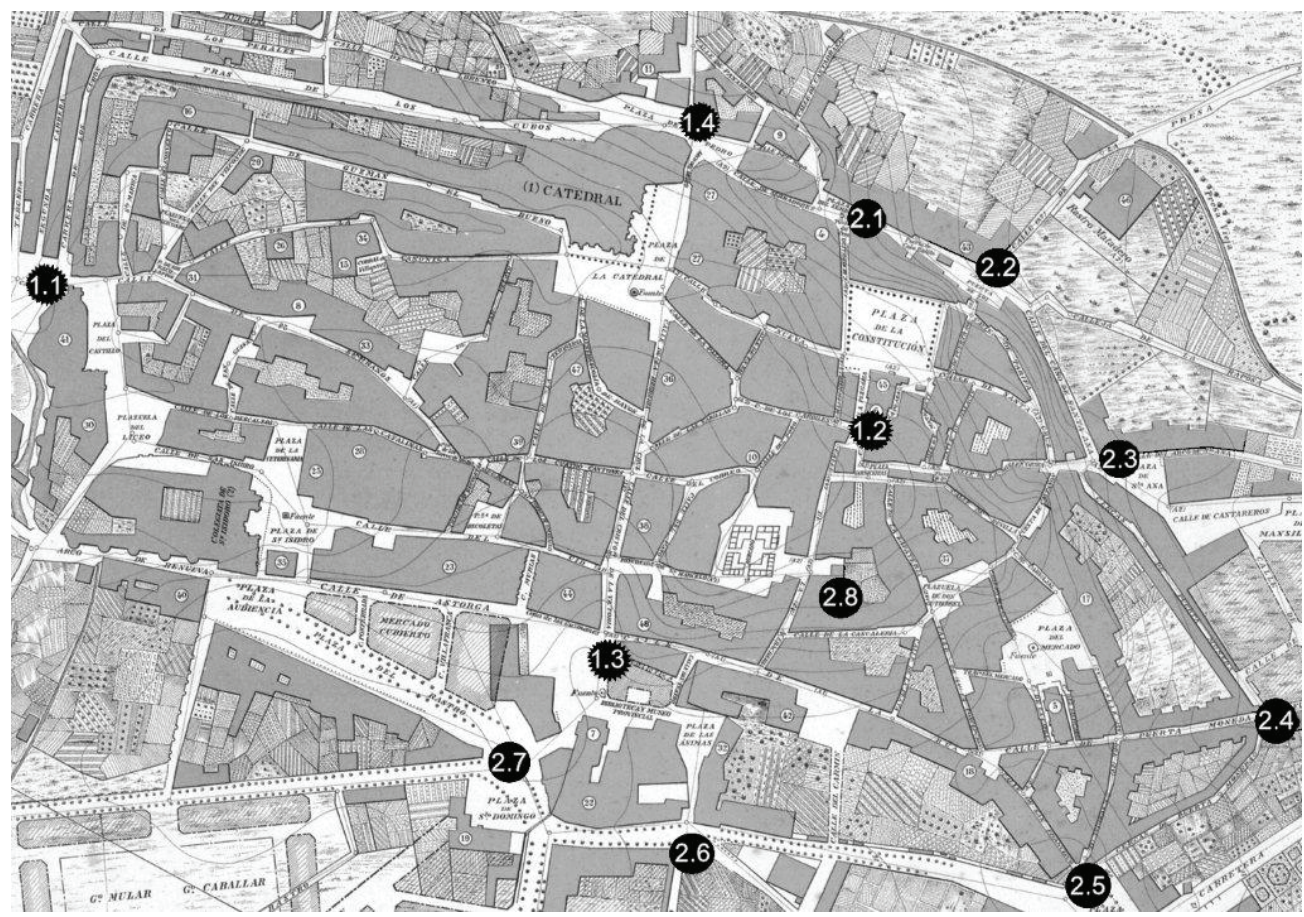

Fig. 2: Plano de situación con las puertas numeradas, realizado sobre el plano de J. M. Ruiz de Salazar (AHML).

\section{Las puertas del recinto romano}

La primitiva muralla, siguiendo la práctica militar de los recintos romanos, tenía cuatro puertas colocadas axialmente hacia los puntos cardinales. No tenemos certeza de su configuración original, pero, por los restos hallados en las últimas excavaciones, podemos deducir que estarían formadas por dos torres cuadrangulares en los extremos y uno o dos vanos de acceso cubiertos por arcos de medio punto, sobre los que correría una galería almenada ${ }^{40}$. También tenían carácter emblemático, pues estaban adornadas con mármoles e inscripciones en las que se honraba a los primeros pobladores, según cuentan las crónicas antiguas ${ }^{41}$.

\subsection{Puerta Decumana}

Emplazada en el lado norte del recinto, desde la Edad Media es conocida como Puerta Castillo, por estar al lado de la fortaleza donde tenía su sede el conde encargado

40 Este modelo es el que establecen para la puerta mejor conocida GARCÍA, Victorino, CAMPOMANES, Emilio y MIGUEL, Fernando, "El solar y el entorno urbano de Santa María de Regla (siglos I-XV)", La catedral de León en la Edad Media, León, 2004, pp. 25-27.

41 Véase por ejemplo RISCO, Manuel, Historia de la Ciudad y Corte de León y de sus Reyes, Madrid, 1792, p. 3. 
de la defensa de la ciudad. Es la única puerta de la ciudad que queda en pie, aunque la estructura que hoy presenta es obra del XVIII, como dijimos más arriba ${ }^{42}$. En ese momento se demolería la romana, de la que no quedan apenas vestigios, para erigir en su lugar la entrada monumental que vemos en la actualidad ${ }^{43}$.

\subsection{Puerta Praetoria}

Situada al sur, fue conocida durante el medievo como Arco de Rege o del Rey, también de Cardiles por dar paso a la calle de ese nombre. Perdió todo su sentido al realizarse en el siglo XIV la Cerca Nueva, dejando entonces de ser entrada a la ciudad y quedando integrada en el tramado urbano medieval sin ninguna utilidad práctica, por lo que es fácil que fuera abatida entonces. Fidel Fita, quien fuera vicepresidente de la Comisión de Monumentos de la Provincia de León, hace una alusión inconcreta al derribo del arco de Cardiles, en el que afirma fueron halladas cinco lápidas romanas $^{44}$, reutilizadas después en la construcción de una bodega en Villamañán ${ }^{45}$. Por esta circunstancia podría deducirse que el arco se desharía alrededor de 1860, cuando el ilustre epigrafista vivió en León ${ }^{46}$. No obstante, no existe ninguna referencia documental en los archivos municipales sobre tal demolición en esas fechas, al contrario de las constantes noticias, acuerdos y controversias que se tienen de los demás derribos. Por lo tanto, resulta poco probable que se hiciera entonces, así que nosotros mantenemos en suspenso la fecha de demolición. Apuntamos, como hipótesis, la posibilidad de que la puerta fuera suprimida mucho antes de que Fita viniera a León y que las lápidas fueran sacadas a la luz en alguna obra que se hiciera en los machones o paredes aledañas a la entrada romana, pero desmantelada como tal anteriormente.

\subsection{Puerta Principalis Dextra}

Llamada Puerta Cauriense desde el medievo, estaba ubicada en el extremo oeste de la vía principalis romana. Al igual que la anterior, y por las mismas razones, dejó de ser operativa en el tramo final de la Edad Media con el nuevo diseño defensivo, por lo que su desaparición fue una consecuencia lógica. El palacio renacentista de los Guzmanes, levantado en el siglo XVI, ocupa parte del espacio que correspondía a la citada puerta, por lo que podemos colegir que, si no había desaparecido ya en el momento de su construcción, dejaría de existir en ese momento ${ }^{47}$.

\footnotetext{
42 La puerta moderna ha sido estudiada y documentada en MORAIS VALLEJO, Emilio, "Puerta Castillo. Una entrada emblemática para la ciudad de León", De Arte, no 3, 2004, pp. 143-163.

43 No nos detenemos en ningún derribo anterior al siglo XIX por exceder el tema de nuestro trabajo.

44 La reutilización de lápidas antiguas con inscripciones como material de construcción de la segunda muralla romana fue una práctica habitual, prueba de ello es que en las labores de restauración realizadas a principios del año 2010 se encontraron más de 50 lápidas romanas en un pequeño tramo de los lienzos defensivos.

45 FITA, Fidel, Epigrafía romana de la ciudad de León, León, 1866, p. 359.

46 Así opina por ejemplo PONGA MAYO, Juan Carlos, (2009), op. cit., p. 43.

47 MORAIS VALLEJO, Emilio y CAMPOS SÁNCHEZ-BORDONA, Ma Dolores, Arquitectura y Patrimonio. Edificios civiles de la ciudad de León en la Edad Moderna, León, 2007, p. 175.
} 


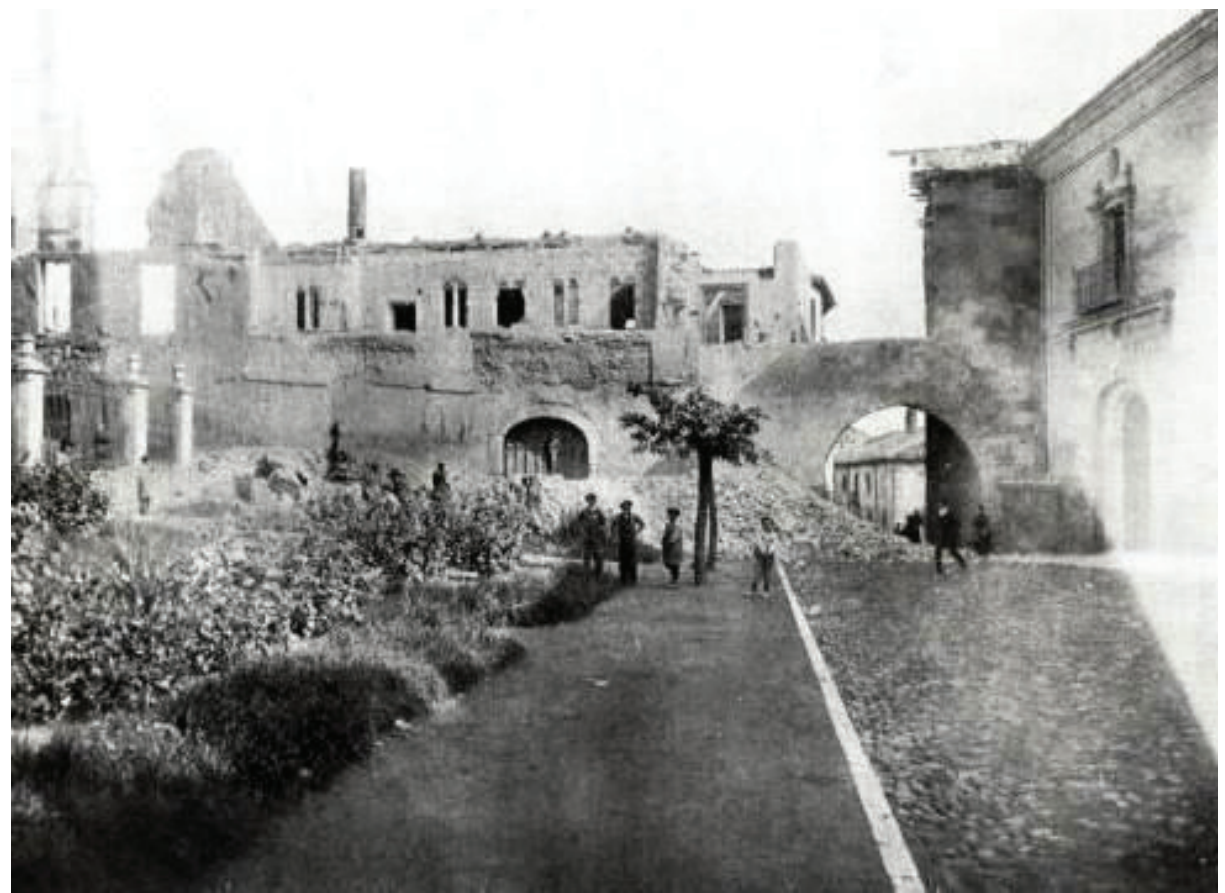

Fig. 3: Vista de Puerta Obispo desde el interior del recinto amurallado, cuando empezó su demolición. A la derecha se puede ver el vano que estaba practicable en el s. XIX.

(Colección particular).

\subsection{Puerta Principalis Sinistra}

Situada al este, fue conocida desde la Edad Media como Puerta Obispo ${ }^{48}$, por estar unida a la catedral por un extremo y al palacio episcopal por el otro. La primitiva puerta romana ya era monumental. Tenía dos vanos cubiertos por arcos de medio punto que daban paso a sendos pasajes empedrados, y estaba flanqueada por dos grandes torres rectangulares entre las que discurría una galería ${ }^{49}$. Posteriormente, tanto en época romana como altomedieval, sufrió profundas modificaciones hasta quedar cerrada. Durante el gótico, probablemente coincidiendo con la terminación del ábside de la actual catedral, se hizo en su lugar una nueva entrada de considerable tamaño y monumentalidad. Se conformaba con una estructura de dos plantas, con buena sillería de piedra, levantada aprovechando en parte los primitivos muros defensivos (fig. 3). En la inferior se abría el acceso que comunicaba el interior de la ciudad con el exterior mediante un amplio pasaje de más de 10 metros con cubierta abovedada, rematado en sus extremos por sendos arcos apuntados de diseño gótico, más

48 Ya era conocida con este nombre al menos desde el año 917, según se recoge en un documento del obispo Frunimio II; véase, SÁEZ, Emilio, Colección documental del archivo de la catedral de León, León, 1987, p. 70.

49 La puerta ha sido estudiada y descrita tras la última excavación practicada en la zona por GARCÍA, Victorino, CAMPOMANES, Emilio y MIGUEL, Fernando (2004), op. cit, pp. 25-27. 
otro interior de similar traza pero menor luz, por cuyo intradós se deslizaba el rastrillo para cerrar el paso. En la planta superior había dos estancias rectangulares, una era un corredor adornado con artesonado del siglo XVI, que ponía en comunicación el palacio episcopal con la catedral a través de la desaparecida Torre del Tesoro. Desde el corredor se accedía por dos puertas (una de ellas con arco apuntado) a una amplia y alargada sala paralela, que llegó a servir de Sala Capitular antes de la construcción del actual claustro renacentista, equipada con una chimenea de sillería decorada con relieves vegetales. Ambas estancias se iluminaban por vanos geminados cubiertos por arcos góticos apoyados sobre columnillas prismáticas. Delante había un patio que en otro tiempo fue cementerio de la parroquia de San Juan de Regla y en sus últimos años almacén de materiales de obra del edificio catedralicio. En el lado oriental se levantó en el siglo XVI un paredón para sostener un nuevo pasadizo entre el palacio y la catedral, del que hoy solo queda una puerta en esviaje situada en altura sobre la sacristía de la catedral, que ya no conduce a ninguna parte porque las dos estancias que comunicaba han desaparecido, resultando sorprendente para quien desconoce su función originaria.

Hasta el siglo XVII se fueron añadiendo nuevas estructuras y locales extraños a la puerta, modificándola hasta formar un conglomerado de edificaciones de varias épocas que escondían en su interior la primitiva entrada oriental de la ciudad ${ }^{50}$, de manera que quedó dentro de las dependencias catedralicias, y por lo tanto impracticable para su finalidad original ${ }^{51}$. En 1609 el conjunto de estos edificios fue destinado por el obispo a sede del Provisorato de la Mitra, y desde 1868 hasta su desaparición sirvió para albergar las oficinas y dependencias de la obra de restauración de la Catedral (fig. 4).

Al resultar inutilizado el acceso, en un momento impreciso del que no tenemos noticia documental, se tuvo que abrir otra nueva entrada a su lado como paso de carruajes, en la misma línea de la muralla y sólo unos metros más hacia el sur, pegada al palacio episcopal. Se conformaba por un sencillo arco de piedra de medio punto sobre jambas pétreas que cerraba un estrecho callejón en forma de embudo (fig. 3).

Finalmente también llegó para la puerta gótica la piqueta. La desaparición está estrechamente relacionada, además de las consideraciones vistas de forma general para el resto, con la restauración historicista de la catedral realizada a finales del siglo XIX e inaugurada en el año $1901^{52}$. En aquellos momentos había una corriente de opinión mayoritaria que estaba a favor de suprimir todos los edificios que la historia había ido dejando adosados a la catedral. La idea era aislarla totalmente, con el fin

50 Se llegó a olvidar, y, cuando a principios del siglo XX iniciaron el derribo, resultó una sorpresa encontrar las estructuras góticas, según cuentan las crónicas de la época.

51 El estudio más interesante para conocer la configuración histórica de la puerta es el que hizo la Comisión de Monumentos para presentar a la Real Academia de la Historia, firmado por DÍAZ JIMÉNEZ, Juan Eloy y ARGÜELLES, Félix, "Un monumento de la ciudad de León", Boletín de la Real Academia de la Historia, $\mathrm{n}^{\circ}$ 58, 1911, pp. 135-140. Véase también, GÓMEZ MORENO, Manuel, Catálogo monumental de España. Provincia de León, León, 1925, p. 289; J. A. GAYA NUÑO, La arquitectura española en sus edificios desaparecidos, Madrid, pp. 177-179; GARCÍA, Victorino, CAMPOMANES, Emilio y MIGUEL, Fernando, (2004), op. cit., pp. 43-44; PONGA MAYO, Juan Carlos, (2009), op. cit., p. 36-40.

52 Sobre la restauración de la catedral véase, RIVERA BLANCO, Javier, Historia de las restauraciones de la catedral de León, Valladolid, 1993; GONZÁLEZ, Ignacio, La catedral de León. Historia y restauración, León, 1993. 


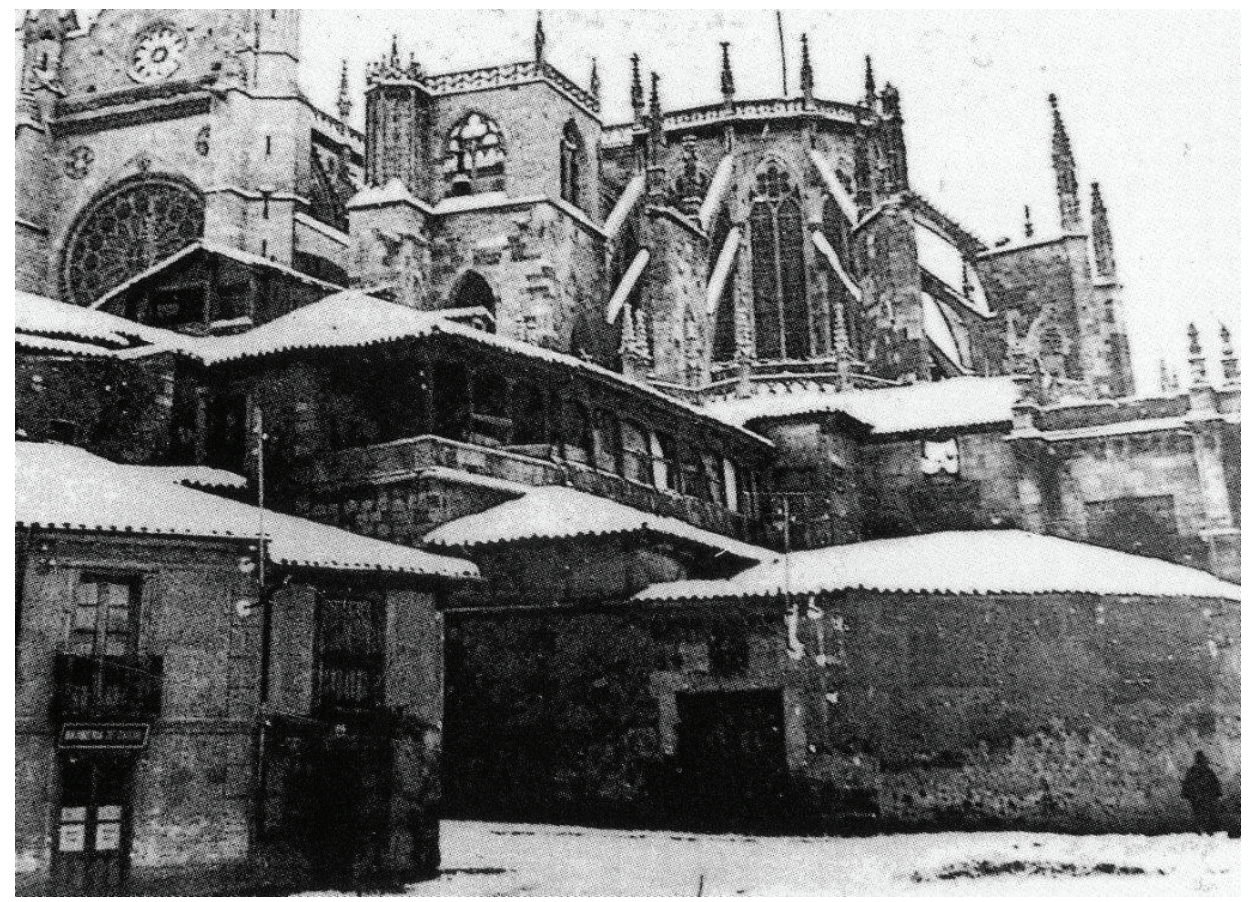

Fig. 4: Vista de Puerta Obispo desde el exterior del recinto amurallado, antes de empezar la demolición, con los edificios que la ocultaban. (Colección particular).

de permitir su visión sin obstáculos que enturbiasen el "prístino" edificio gótico que había conseguido la intervención decimonónica ${ }^{53}$. El principal valedor del plan fue Demetrio de los Ríos, arquitecto restaurador de la catedral y vicepresidente de la Comisión Provincial de Monumentos Históricos y Artísticos de León. El asunto ya había sido tratado en la reunión de la citada Comisión el 6 de diciembre de 1883, en la que se llegó a la conclusión de que las estructuras lindantes con la catedral carecían de valor artístico y podían suprimirse ${ }^{54}$. Aunque las autoridades no aprobaron en aquel momento la demolición, la idea iba ganando cada vez más partidarios. Así pues, fue el aislamiento de la catedral, y no problemas viarios de circulación como se ha dicho en ocasiones, el principal motivo del derribo, ya que el paso quedaba libre con el arco abierto que citamos más arriba. De hecho, a finales del año 1875, en

\footnotetext{
53 Sobre la supresión de las edificaciones adheridas a las catedrales, es elocuente el trabajo de TORRES BALBÁS, Leopoldo, "El aislamiento de nuestras catedrales", Arquitectura, 1919, pp. 358-362, quien, en época cercana al hecho que tratamos, alertaba sobre los peligros derivados del aislamiento, tanto en aspectos estéticos, como de significado o escala, con la consiguiente pérdida de vestigios del pasado, verdaderos documentos históricos.

${ }^{54}$ Libro de Actas de la Comisión Provincial de Monumentos Históricos y Artísticos de León (1883-1898), Biblioteca Pública de León, C. M. 615, fol. 7 y ss.: ...la supuesta muralla contigua al ábside de la Catedral no existe desde muy antiguo y por consiguiente no se le puede atribuir valor alguno artístico, siendo por otra parte de todo punto necesario lo que se propone por el Director de las obras de restauración en su memoria a fin de realizar el completo desarrollo de aquella parte del edificio.
} 
plena fiebre demoledora, hubo una propuesta para actuar en la rasante de la vía que pasaba bajo dicho arco con el fin de mejorar el tránsito, adaptándose a las necesidades de circulación sobrevenidas, sin que hubiera en aquella ocasión ninguna intención de desmantelarlo ${ }^{55}$.

El Ayuntamiento se convirtió en el primer interesado en hacer desaparecer la antigua puerta y las construcciones adosadas a ella, que conformaban una especie de "caserón" (como se denomina en la documentación) informe y deteriorado, aunque alojaba vestigios históricos y artísticos de gran importancia. La Corporación municipal, con su alcalde Alfredo Barthe a la cabeza, hizo valer todos los recursos que tenía a su alcance para conseguir la demolición, desde su capacidad administrativa o política hasta la manipulación de la prensa local, destacando en este sentido las crónicas firmadas por Clemente Bravo. Lo primero fue convencer a la Comisión de Monumentos Provincial para que autorizara el derribo y después solicitar permiso a las autoridades estatales para hacerlo ${ }^{56}$. Lo siguiente era demostrar la propiedad del Estado, no de la catedral ${ }^{57}$, y así las autoridades eclesiásticas no podrían oponerse a su desaparición ${ }^{58}$. Al tiempo fue creándose un estado de opinión favorable al aislamiento del edificio catedralicio, utilizando para ello las tertulias más influyentes y artículos de opinión insertos en los periódicos de la ciudad. El paso final consistía en convencer al ministerio de Instrucción Pública para que permitiera la demolición y que la subvencionara. Así, el 29 de julio de 1910 el alcalde dio cuenta de las razones esgrimidas ante el ministerio para justificar el derribo del caserón, siendo la primera dejar al descubierto las bellezas artísticas de la catedral, pero se añadieron otras para reforzar el alegato:

Se exponen los fundamentos en que se apoya la opinión de que pertenece al Estado y los motivos históricos, artísticos, de higiene, de facilidad de tránsito, de conveniencia de la catedral, de desahogo de las oficinas alli establecidas, de seguridad por el peligro que las maderas alli depositadas para la iglesia próxima y otras muchas que aconsejan reclamar el inmediato derribo de tan feo edificio ${ }^{59}$.

Aunque la Comisión de Monumentos, en su sesión del 11 de mayo de 1910, había probado la importancia de los restos encontrados ${ }^{60}$, el 3 de agosto siguiente resolvió

55 AHML, caja 96, $\mathrm{n}^{\circ}$ 155, 18 de diciembre de 1875, s/f.

56 Biblioteca Pública de León (desde aquí BPL), Libro de Actas. Comisión Provincial de Monumentos Históricos y Artísticos de León (1898-1921) (CPMHAL), C. M. 616, s/f. El acta de 30-IV-1910 dice: ...del edificio del antiguo Provisorato ... cuya demolición se ha propuesto al Ministerio, y que convendría estudiar antes de insistir y continuar las gestiones ... se acordó inspeccionar dichas obras ... para mejor conocimiento de lo que proceda.

57 RODRÍGUEZ, Justiniano, "El derribo de la Casa de "Puerta Obispo". Su perfil histórico y jurídico", Tierras de León, $\mathrm{n}^{\circ} 18,1973$, analiza los aspectos jurídicos para demostrar que el edificio era propiedad eclesiástica y que por lo tanto se violentó la ley con su derribo.

58 En julio de 1910 el Ayuntamiento recibió un telegrama del Subsecretario de Instrucción Pública en el que se informaba que el caserón de Puerta Obispo pertenecía al Estado. Cf. AHML, Libro de Actas n ${ }^{\circ}$ 9, fol. 178.

59 AHML, Libro de Actas $\mathrm{n}^{\circ}$ 9, fol. 178.

60 BPL, Libro de Actas CPMHAL..., C. M. 616, s/f.: dando noticia del descubrimiento de dos crugias del siglo trece, construcción coetanea de la catedral que fueron Sala Capitular en otro tiempo; y en la muralla que la sostiene poterna de mérito arqueológico, histórico y artístico, todo lo que debe conservarse a su juicio. 
proponer al Gobierno el derribo de la puerta y las construcciones adheridas. No obstante, atendiendo a la posibilidad de que se hallaran restos antiguos de importancia, aconsejaba proceder al derribo de manera que: se garantice la conservación de lo que se descubra y sea de mérito arqueológico, histórico o artístico y digno de conservarse ${ }^{61}$, prevención que finalmente no fue cumplida, pues ningún resto se conservó de aquella histórica construcción, y eso a pesar de que el Académico Eloy Díaz Giménez dijera que: en opinión de los inteligentes aquellos restos son el único ejemplar de construcciones civiles que nos quedan ${ }^{62}$. Constatamos así la lamentable inoperancia de la Comisión en defensa del patrimonio.

Finalmente los argumentos municipales debieron de ser convincentes ya que el ministerio mandó proceder al derribo por una Real Orden de 13 de agosto de 1910, para lo cual aprobó un gasto que se pagaría con cargo al presupuesto del Ministerio de Instrucción Pública y Bellas Artes ${ }^{63}$. La obra de demolición empezó de inmediato, pero en septiembre fue paralizada debido al recurso interpuesto por el obispo y el cabildo catedralicio, lo cual enojó enormemente a la Corporación municipal, que buscó todas las medidas posibles para reanudar los trabajos ${ }^{64}$. Las actuaciones llevadas a cabo ante las más altas instituciones, en la que se implicaron ministros y personajes leoneses influyentes en la Corte, dieron fruto y el obispo desistió de su intención inicial, por lo que finalmente se llevó a efecto el derribo completo de la histórica puerta ${ }^{65}$. De hecho, el Ayuntamiento aprobó en octubre la utilización de los escombros resultantes en la pavimentación de algunas calles de la capital; triste final para la otrora altiva entrada defensiva de la ciudad ${ }^{66}$. Los trabajos se dilataron hasta principios del año 1911, siendo supervisados por Manuel de Cárdenas, arqui-

61 BPL, Libro de Actas CPMHAL..., C. M. 616, s/f.

62 Ibídem.

63 Así lo recoge la Gaceta de Madrid de 7 de marzo de 1911, p. 654: Resultando que en virtud de lo dispuesto en la Real orden de 13 de Agosto último, que mandó proceder al derribo de la casa en cuestión ...S. M el REY (q. D. g.), de acuerdo con el Consejo de Ministros, ha tenido á bien aprobar el referido proyecto por su indicado presupuesto de 15.481,21 pesetas, y estimando dichas obras como ejecutadas y á ejecutar por el sistema de administración, disponer que se paguen con cargo al expresado capítulo, articulo y concepto del vigente presupuesto de gastos de este Ministerio, y que esta resolución se inserte en la Gaceta de Madrid a los efectos prevenidos en el mencionado Real Decreto de 24 de Agosto de 1910.

64 AHML, Libro de Actas n $\mathrm{n}^{\circ}$ 10, fols. 13-15: ...el Sr. Ureña extrañándose de que el Obispo y el Cabildo vayan contra la opinión, cuando el Ayuntamiento y todos trabajan en pro de los intereses materiales de León, ellos, dice el Sr. Ureña, quieren entorpecer este proyecto; y pide que se constituya en sesión permanente este Excmo. Ayuntamiento hasta que venga la orden autorizando la continuación del derribo, y si esta medida les pareciese violenta, entonces que se dirija al Sr. Presidente del Consejo de Ministros y ministerio de Instrucción Pública telegramas, $u$ oficios protestando de la supresión.

65 AHML, Libro de Actas $\mathrm{n}^{\circ}$ 10, fol. 17: ...refiere el Sr. Presidente lo que ha hecho en el asunto del derribo del caserón y dice que cumpliendo lo acordado dirigió telegramas a los Excmo. Srs. Presidente del Consejo de Ministros y Ministros de la Gobernación e Instrucción Pública y a los Srs. Azcárate y Dato, que todos los Srs. Ministros han contestado ofreciendo atender la petición del Ayuntamiento de conformidad con los deseos del público; que también ha contestado en el mismo sentido el Sr. Azcárate ...termina dando cuenta de la visita hecha al Prelado, el cual desistió de su primera actitud participando de oficio al ministro, que en su vista mandó continuar el derribo.

66 AHML, Libro de Actas n ${ }^{\circ}$ 10, fol. 25: ...pide el Sr. del Río que los escombros que provengan del derribo del Caserón se lleven a calles que necesiten recebo, citando la calle de la Palomera y la calleja de los Difuntos ...termina diciendo que los Srs. Concejales que deseen que se lleven escombros a algún sitio le pasen nota. 
tecto municipal, y con la oposición de Juan Crisóstomo Torbado, arquitecto de la catedral en esas fechas.

\section{Las puertas de la Cerca Nueva}

La muralla medieval tuvo varias puertas, unas fueron realizadas al mismo tiempo que los lienzos, mientras otras fueron abiertas con posterioridad. Su ubicación no responde a un esquema lógico o proporcional como en la obra romana, sino que, lo mismo que el trazado de la muralla es más orgánico que geométrico, los accesos se acomodaron donde parecían más útiles a la ciudad y la regulación de las comunicaciones, con independencia de simetrías u otras consideraciones urbanísticas. Sobre su configuración y aspecto poco podemos saber, por lo que ya dijimos más arriba. En origen las suponemos, por similitud cronológica con otras similares, realizadas con aparejo de piedra, provistas de un acceso de doble arco y bóveda para cubrir el pasadizo interior, protegidas con torres y parapetos almenados para dar mayor aspecto defensivo; pero poco más podemos aventurar. Sirva de ejemplo característico la descripción que se hizo de la Puerta de San Francisco:

Puerta entre dos formaciones torreadas, de la modalidad predominante en el siglo $X V I$, a saber torres prismáticas, de dos pisos, almenadas en su origen $y$, entre una y otra, arco y andana de enlace los que enmarcan en su parte inferior una puerta de dos hojas. Presentando hiladas de sillería en la parte de la base de las torres y en las aristas laterales. El conjunto es de mampostería de cal y piedra ${ }^{67}$.

No obstante, al llegar el siglo XIX habría una gran variedad de formas, debido tanto a las distintas fechas de ejecución y la finalidad con la que fueron abiertas, como a las alteraciones sufridas en el transcurso de los siglos.

A continuación relatamos la historia individual del desmantelamiento de cada una de las puertas de la Cerca Nueva, teniendo como base fundamental la documentación inédita que hemos localizado en el Archivo Histórico Municipal de León, que tras un detenido análisis nos ha permitido entender el proceso demoledor en su contexto.

Por lo que sabemos, todas las entradas a la ciudad tenían al menos un vano cubierto con bóveda, por lo que muchas veces la documentación utiliza el término "arco" en vez de puerta. Hemos constatado que en ocasiones lo que se pretende es solo desmantelar aquel por presentar un estado ruinoso, pero dejando en pie los machones, entre otras razones porque en muchas casos se apoyaban en ellos edificaciones particulares y no era posible suprimirlos sin peligrar la estabilidad de estas. Así, se destruye la estructura que otorga el carácter de puerta, pero se mantiene la anchura del vano, hasta una segunda fase en la que se desmantelan también los soportes. No obstante, siempre que las circunstancias lo permitían, la opción era derribar por completo la puerta y la mayor parte de muralla adosada posible. De hecho, salvo pequeñas excep-

67 PONGA MAYO, Juan Carlos, (2009), op. cit., p. 32, copia esta transcripción del Expediente General de Fortificación. 
ciones poco relevantes, no ha llegado a nuestros días ningún vestigio importante de las puertas históricas de la Cerca Nueva.

\subsection{Puerta del Peso de la Harina}

Empezamos con ella el relato de la demolición de las puertas medievales, siguiendo para las demás el orden que determina el sentido de las agujas del reloj (fig. 2$)^{68}$. Se hallaba ubicada en la parte oriental del perímetro amurallado, justo en la intersección de la muralla romana con la medieval, por lo que se apoyaba en ambas, dando paso a la calle conocida como Cal de Escuderos, que desemboca en la Plaza Mayor. Al parecer, su nombre deriva del impuesto o alcabala que cobraban allí sobre la harina y el pan que entraba en la ciudad, aprovechando la cercanía de los molinos harineros de la Presa Vieja. En otra época se llamó Puerta del Gallo, probablemente por ser la más oriental y la primera en ver aparecer el sol, que el gallo anuncia. Estaba bien defendida por la proximidad de la famosa y sólida Torre de los Ponce, de origen romano e integrada en el primitivo recinto campamental.

No se han encontrado referencias concretas del momento de su demolición, pero en cualquier caso tuvo que realizarse poco antes de noviembre de 1854, pues el 23 de ese mes el Ayuntamiento acordó que la Sección de policía analizara y propusiera la actuación más conveniente a realizar en el espacio que había quedado libre a consecuencia del derribo del Arco del Peso de la Harina que se acababa de hacer ${ }^{69}$.

Años más tarde, en 1868, todavía existía un machón de la antigua puerta, que estaba integrado en la estructura de la casa de un particular, el cual solicitó su demolición, pues presentaba una deformidad que afectaba a la estabilidad de su vivienda. El Ayuntamiento aceptó la petición tras ver el dictamen del arquitecto municipal, con las condiciones siguientes: que se encargara de ello el propio vecino, que no hubiera perjuicio a terceros, que el material resultante del derribo fuera para el municipio y que edificara de inmediato allí, con el objetivo de adecentar el lugar ${ }^{70}$. Todo esto debió ejecutarse, pero con cierto retraso, pues la ratificación del acuerdo fue aprobado bastante tiempo después, en la reunión celebrada en noviembre de $1870^{71}$.

\subsection{Puerta Sol}

Su nombre está asociado a su situación en la zona oriental, orientada a la salida del sol. También denominada en ocasiones Puerta de Rodezneros o Escabecheros, en

68 No utilizamos el orden cronológico por no ser significativo para nuestro tema, pues los criterios de demolición no cambian con el paso del tiempo. Creemos más útil el orden geográfico para facilitar la ubicación en el plano.

69 AHML, caja 93, $n^{\circ}$ 145, s/f: ...que la sección de policía proponga lo que crea deba ejecutarse en el espacio que ha quedado entre las dos casas... a consecuencia del derrivo del Arco del Peso.

70 AHML, caja 95, n 151, fol. 32 v y 33 r: Visto un memorial de D. Marcelino Prieto Castillo solicita que se le ceda el machón o espacio que ocupa el machón o muro del antiguo Arco del Peso de la Arina, a la salida de la Plaza por estar enclavado en una casa suya con luces sobre él y presentar una deformidad en aquel sitio.

71 AHML, caja 95, n 152, fol. 57 r: Como proponen la Comisión de policía y el Arquitecto se concede a D. Marcelino Prieto Castillo y D. Norberto Arévalo por mitad el espacio que ocupa el estrivo del arco del Peso de la harina para que edifiquen en el término de un año. 


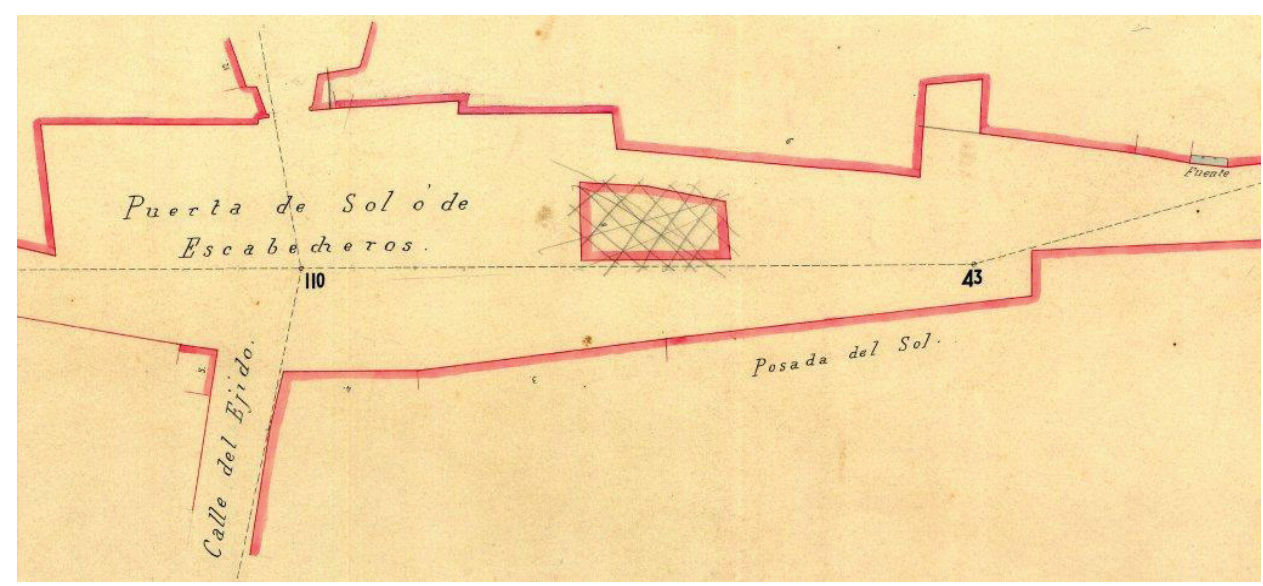

Fig. 5: Plano de la zona de Puerta Sol en el siglo XIX (las tachaduras son originales) (AHML).

alusión a los gremios ubicados en sus inmediaciones. Por el citado plano de Otermín y por el conservado en el Archivo Municipal (fig. 5) ${ }^{72}$, da la sensación de que era de un solo vano y estaba flanqueada en su lateral septentrional por una torre de base rectangular.

La sentencia de muerte de esta puerta podemos decir que se firmó en el ayuntamiento del 10 de junio de 1864, pero su ejecución fue mucho más tardía. En aquella fecha se acordó su demolición, pero no porque estuviera en mal estado de conservación -recordamos que la puerta fue arreglada en 1840 para abrirla tras la Guerra Carlista-, sino, por carecer de categoría artística, constituir un obstáculo para la circulación, además de alegar razones de higiene pública, según recoge el libro de actas municipal ${ }^{73}$. A partir de ese momento se inicia un complicado proceso que se dilatará en el tiempo mucho más de lo habitual. En julio sale a subasta pública la obra por la cantidad de 6.000 reales y con venta de los materiales del derribo ${ }^{74}$; en septiembre, ante la ausencia de licitadores, el Ayuntamiento decide hacerse cargo de los trabajos, pidiendo para ello autorización al Gobernador ${ }^{75}$. Probablemente este no diera permiso, pues un año más tarde el Ayuntamiento vuelve a retomar la iniciativa acordando la demolición, ahora autorizada, según consta en el acta correspondiente ${ }^{76}$.

72 Se conserva una colección de 36 hojas de detalle del plano de la ciudad de León a escala 1/250, realizada en una fecha indeterminada del siglo XIX, que puede ayudar a interpretar algunas puertas. AHML, caja 727, $\mathrm{n}^{\mathrm{o}} 61$.

73 AHML, caja 95, n 149, 10 de junio de 1864, s/f: Se acuerda derribar el Arco de Puerta Sol, por no tener importancia de ninguna clase y constituir un obstáculo para el libre y desahogado tránsito, y para la ventilación.

74 AHML, caja 95, n 149, 12 de julio de 1864, s/f. ...sirviendo de tipo para la admisión de posturas la cantidad de seis mil reales líquidos para los fondos municipales, elevándose este acuerdo al Sr. Gobernador para su aprobación o lo que proceda.

75 AHML, caja 95, $\mathrm{n}^{\circ}$ 149, 21 de septiembre de 1864, s/f. ...se acuerda que se ejecute dicho derribo por administración, previa autorización del Sr. Gobernador.

76 AHML, caja 95, n 150, fol. 43 r: ...que se lleve a efecto el derribo del Arco de Puerta de Sol ya autorizado. 
Desconocemos los motivos por los que tampoco se hizo efectiva en ese momento, pues nada se cuenta de ello en los escritos municipales, pero el caso es que en el año 1875 todavía no se había ejecutado. El acta del 7 de octubre recoge un nuevo acuerdo de derribo, una vez que el expediente parece estar definitivamente terminado y después de haber conseguido la pertinente autorización ${ }^{77}$. Pero el 20 del mismo mes la Comisión de Monumentos acuerda solicitar la interrupción de las obras ${ }^{78}$. El contratista que había concertado el desmonte presentó poco después al Ayuntamiento una cuenta que ascendía a setecientos reales por su trabajo, que había detenido el Gobernador cuando estaba en plena ejecución ${ }^{79}$. En ningún momento la documentación trata sobre las causas esgrimidas para la paralización, pero con toda probabilidad sería en atención a los criterios defendidos por la citada Comisión. No obstante, parte de la muralla contigua a la puerta se demuele entonces, pues leemos en el acta municipal del 11 de diciembre de 1875 la contratación del transporte del material resultante con destino a la obra de la carretera del Rastro, en ejecución entonces, utilizando una práctica habitual ya mencionada ${ }^{80}$. El derribo de Puerta Sol no parecía tener solución, pues a primeros de 1877 todavía el Ayuntamiento apremia para que se hagan las diligencias oportunas y resolver la suspensión de las obras ${ }^{81}$. Un año más tarde, la Corporación municipal, ciertamente hastiada por el asunto, recuerda al Gobernador los muchos años que lleva suspendida la demolición esperando que la autoridad competente resolviera sobre la conservación, sin que el asunto estuviera zanjado todavía, por lo que le insta a acelerar los trámites con el fin de terminar definitivamente con una cuestión demasiado tiempo encallada ${ }^{82}$. En abril de 1878, catorce años después de iniciado el proceso, el Ayuntamiento apremió al Gobernador para que alzase la suspensión del derribo ${ }^{83}$, a lo que debió acceder pronto, pues en el acta del día 11 ya se recoge el acuerdo para extender el derribo de Puerta Sol a todo el macizo sobre el que se apoyaba, y no solo al arco como se pensaba en principio ${ }^{84}$.

77 AHML, caja 96, $\mathrm{n}^{\circ}$ 155, 7 de octubre de 1875, s/f: ...que se proceda al derribo del Arco de Puerta Sol, una vez que el expediente está terminado en forma.

78 Libro de Actas de la Comisión Provincial de Monumentos Históricos y Artísticos de León (1898-1921), Biblioteca Pública de León, C. M. 614, fol. 62 r.

79 AHML, caja 96, $\mathrm{n}^{\circ} 155,4$ de noviembre de 1875, s/f: Se vio una cuenta que presenta el encargado de la obra de derribo del Arco de Puerta Sol, suspendida por orden del Gobernador... se acuerda que pase todo a la Comisión de policía y arquitecto para que arreglen el asunto con el encargado de dicha obra.

80 AHML, caja 96, $\mathrm{n}^{\circ}$ 155, 11 de diciembre de 1875, s/f: ...deseando aprovecharse todo el morrillo y demás desmonte de la muralla contigua al Arco de Puerta Sol en el afirmado de la carretera del Rastro, se ha contratado el transporte de aquel material...

81 AHML, caja 96, $\mathrm{n}^{\circ}$ 157, 11 de enero de 1877, s/f: ...que se hagan las gestiones necesarias a fin de que se resuelva el expediente relativo a la suspensión del derribo del Arco de Puerta Sol.

82 AHML, caja 97, $\mathrm{n}^{\circ}$ 158, fol 4 r: Se acuerda que se haga presente al Sr. Gobernador que hace ya años se suspendió por orden suya el derribo del Arco de Puerta Sol a fin de que se resolviese por la superioridad si debía o no conservarse, y que a pesar del tiempo transcurrido la suspensión continua, y urge por consiguiente que cese este estado de cosas, y que se le encarezca la necesidad de que escite a quien corresponda a que dicte resolución.

83 AHML, caja 97, $\mathrm{n}^{\circ}$ 158, fol. 30 r. Habiéndose recurrido al Sr. Gobernador para que alce la suspensión de derribo del arco de Puerta Sol se acuerda que si esta autoridad resuelve como se pide se proceda sin levantar mano a demoler el arco.

84 AHML, caja 97, $n^{\circ} 158$, fol. 31 v: Se acuerda que el derribo del arco de Puerta Sol se estienda a todo el macizo que formaba parte de su fábrica. 


\subsection{Puerta Santa Ana}

Por otra denominación Puerta Cal de Moros, debido al nombre de la calle adyacente. Esta entrada meridional de la ciudad daba paso a la parroquia de Santa Ana, de ahí su título principal. Las últimas excavaciones confirman que estaba formada por dos torres rectangulares, escalonadas en dos niveles, que flanqueaban un único paso abovedado $^{85}$. En marzo de 1852 el arquitecto municipal hizo un informe en el que aconsejaba su derribo por hallarse en estado de ruina, además de esgrimir la mejora consiguiente para la circulación de la zona ${ }^{86}$. El Ayuntamiento acepta el informe y pide un nuevo dictamen a la Sección de policía, la cual ratifica a los pocos días los argumentos del arquitecto ${ }^{87}$. A la vista de la coincidencia de opiniones, se acuerda proceder a la demolición con arreglo a las condiciones fijadas por el arquitecto municipal. Por fin, el 17 de abril de 1852 se anuncia el remate del derribo ${ }^{88}$, que se debió de realizar de inmediato pues el día 29 del mismo mes un vecino ya está pidiendo indemnización por los daños causados por los trabajos ${ }^{89}$. El mismo vecino, pocos días después, elevó otro memorial al Ayuntamiento quejándose de la lentitud con que estaban extrayendo los escombros del arco demolido, lo cual debía ser cierto pues se acuerda conminar al contratista para que los retire inmediatamente. Por todo esto deducimos que el desmonte ya estaba consumado en esa fecha ${ }^{90}$.

Como en ocasiones similares, el Ayuntamiento aprovechó el derribo para alinear la calle, lo cual siempre perjudicaba a algún vecino. En esta ocasión un particular tuvo que retirar la fachada de su casa para seguir el nuevo trazado público, perdiendo terreno y teniendo que hacer de nuevo el frente de su propiedad, por lo que pidió indemnización ${ }^{91}$. En principio el Ayuntamiento se negó a pagar alegando que los daños eran por haber edificado la casa apoyada sobre la muralla, de propiedad pública, sin tener autorización para ello ${ }^{92}$. No obstante, tras la intervención del Gobernador, en septiembre de 1854 se acordó abonar 1.700 reales por los gastos ocasionados en la reconstrucción de la casa, con la condición de que retirase la fachada hasta la línea fijada ${ }^{93}$. En octubre del mismo año todavía hay informes sobre la finalización del de-

85 GARCÍA MARCOS, Victoriano, Informe de la excavación de la Puerta de Cal de Moros, Ayuntamiento de León, 2010.

86 AHML, caja 93, $\mathrm{n}^{\circ}$ 143, fol. 25 v y 26 r: Se vio un informe del Sr. Arquitecto relativo al estado del Arco de Santa Ana en que manifiesta que debe procederse a su derrivo, ya por hallarse bastante ruinoso e que por dar más amplitud y desahogo al tránsito público...

87 AHML, caja 93, no 143, fol. 28 v: Se vio un informe de la Sección de Policía en que propone que se derrive el Arco de Santana.

88 AHML, caja 93, n 143, fol. 37 r: ....se acuerda anunciar el remate del derrivo del Arco de Santa Ana.

89 AHML, caja 93, $\mathrm{n}^{\circ}$ 143, fol. $41 \mathrm{r}$ : Se vio un memorial de D. Manuel Mercadillo relativo a que se le avonen los daños y perjuicios que se causan a una casa de su pertenencia con motivo del derrivo del Arco de Santa Ana.

90 AHML, caja 93, $\mathrm{n}^{0}$ 143, fol. $52 \mathrm{r}$....Se vio un memorial de D. Manuel Mercadillo, en que se queja de la lentitud con se procede a la extracción de los escombros del Arco de Santa Ana.

91 AHML, caja 93, $\mathrm{n}^{\circ}$ 143, fol. $107 \mathrm{r}$ y v. ... debiendo retirarse la fachada de dicha casa de cuatro y medio a cinco pies cuadrados... por los gastos que le ha de ocasionar el derrivo y nueva construcción de la fachada...

92 Ibídem.

93 AHML, caja 145, 14- IX - 1854, s/f ...abonarle mil setecientos rs. con la condición de que retire la fachada... 

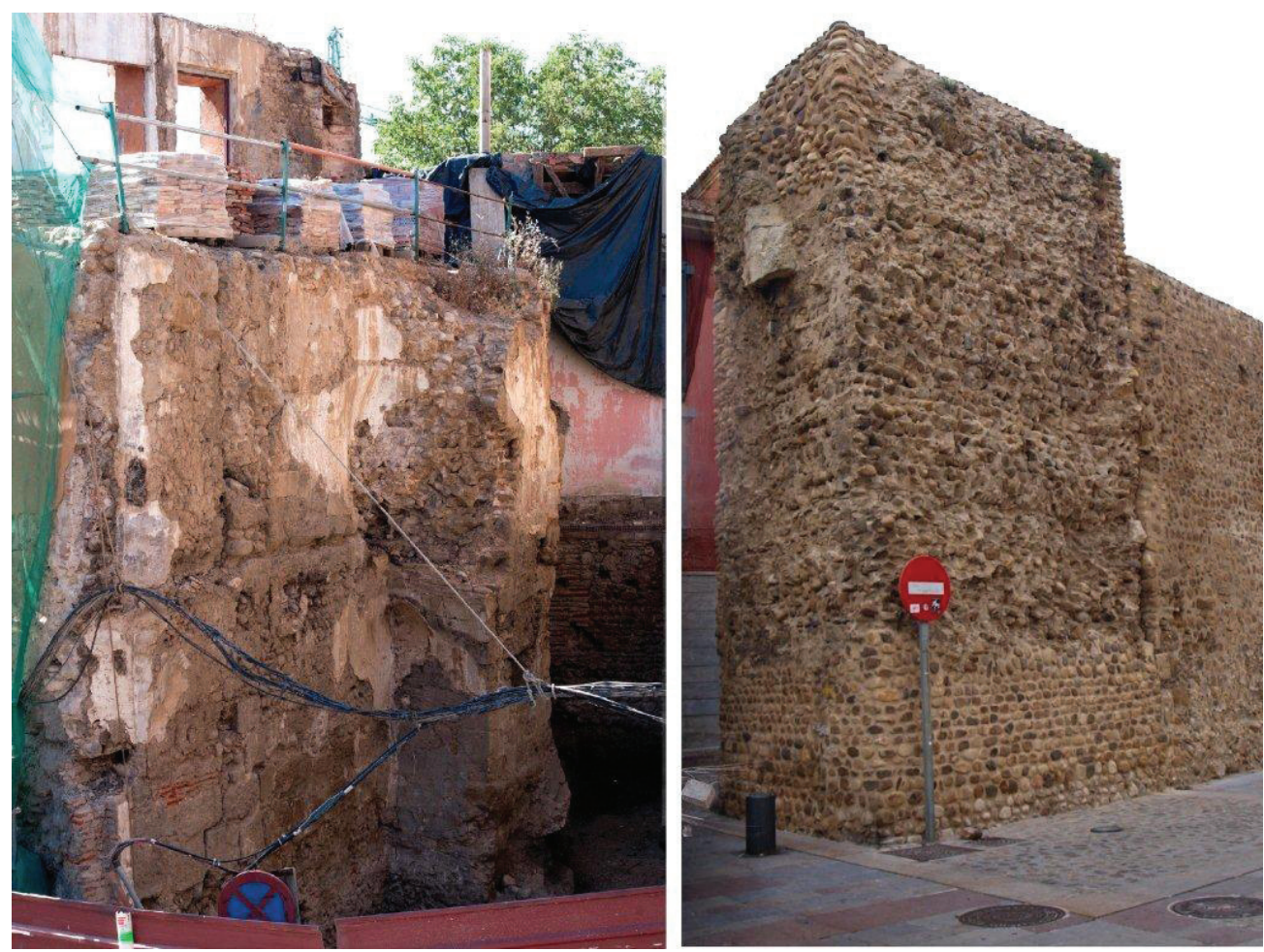

Fig. 6: Restos actuales de Puerta Santa Ana y Puerta Moneda (Foto de Puerta Santa Ana cedida por Victoriano García).

rribo de los soportes del arco y la alineación de la casa implicada ${ }^{94}$. En noviembre ya estaba desmantelada la puerta, como prueba el pago de los jornales invertidos en la obra $^{95}$. No obstante, no fue demolida del todo pues hace poco ha aparecido parte de la estructura de una de las torres, utilizada en la construcción de una casa recientemente derribada (fig. 6).

Años más tarde, en 1870, se aprueba el desmantelamiento del baluarte que había servido para defender la puerta, porque estaba en estado de ruina manifiesta ${ }^{96}$. De nuevo el desmonte produjo daños en la casa de un vecino del lugar, que hubo de reparar el Ayuntamiento por su cuenta tiempo después ${ }^{97}$.

94 AHML, caja 145, 19 de octubre de 1854, s/f: Se acuerda que reconozca el Arquitecto el derrivo verificado en el Arco de Santa Ana y haga que el rematante cumpla las condiciones del remate, si no las hubiere cumplido; y si para proceder a la obra que a fin de alinear su casa de fuera de dicho arco tiene que hacer el Sr. Mercadillo...

95 AHML, caja 145, 2 de noviembre de 1854, s/f: Se acuerda que se paguen de imprevistos mil setenta y cuatro rs. treinta y dos mr., importe de los jornales invertidos en el derrivo del estrivo del Arco de Santana.

96 AHML, caja 95, n $\mathrm{n}^{\circ}$ 152, fol. 20 r: ... ha sido preciso apoyar una parte del baluarte de la antigua Puerta de Santa Ana por hallarse ruinoso, se acuerda que se proceda a su derrivo.

97 AHML, caja 96, n 153, 27 de marzo de 1873. s/f: Queda enterado el Ayuntamiento de que se ha reparado el daño causado en la casa de D. Agustín Gómez al derribar el estribo del antiguo Arco de Santa Ana. 


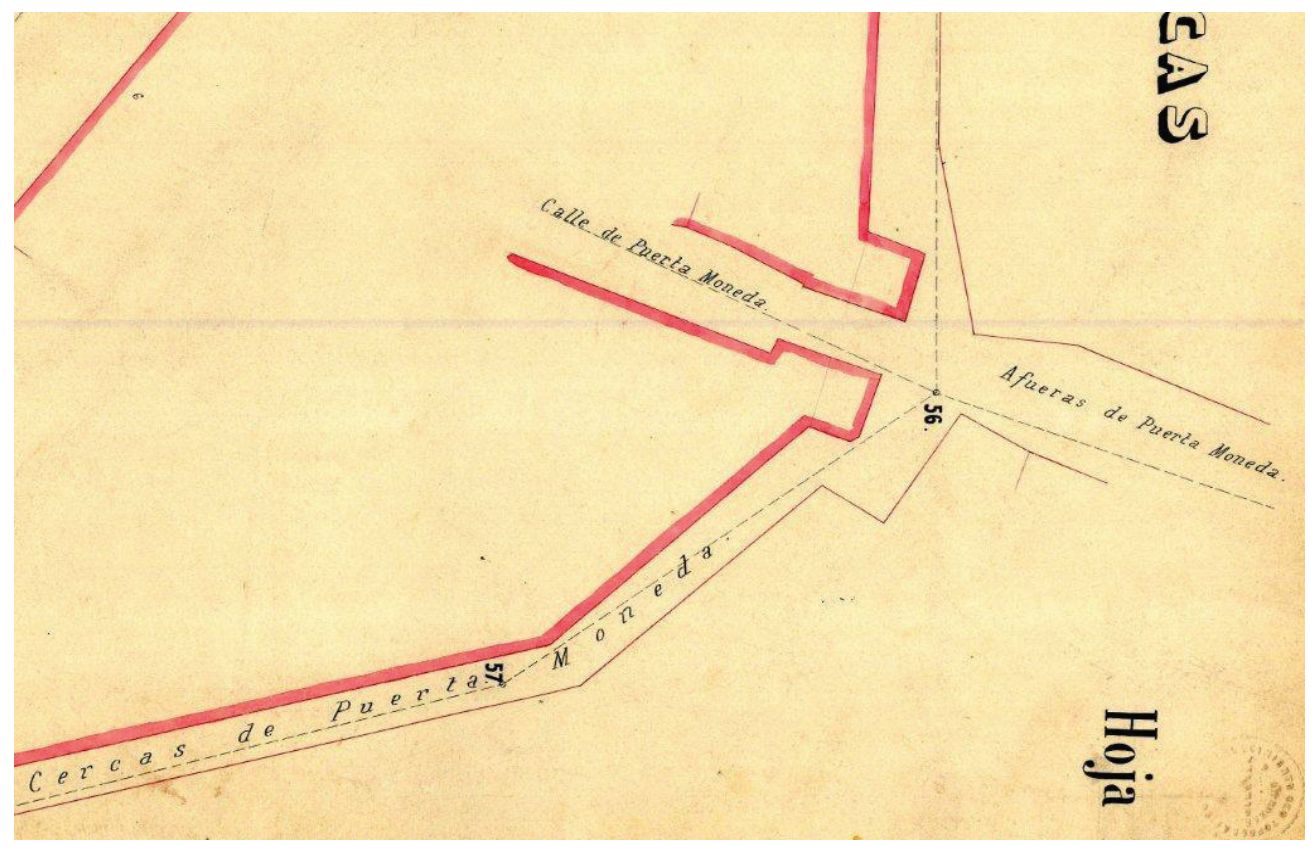

Fig. 7: Plano de la zona de Puerta Moneda en el siglo XIX (AHML).

\subsection{Puerta Moneda}

El nombre puede provenir del impuesto de mercancías que se cobraba a los comerciantes que venían por el Camino Francés y entraban por ella para vender sus productos en la cercana plaza del Mercado, o quizás por los cambistas establecidos en sus inmediaciones. Parece ser que estaba flanqueada por dos torres prismáticas, a la vista del plano urbano de la época (fig. 7), entre las que volaría el arco de entrada y la galería almenada. Estuvo decorada con una estatua pétrea de Carlos III, situada en la parte superior del arco desde 1759 hasta su desmantelamiento ${ }^{98}$, siendo trasladada entonces al museo arqueológico de San $\operatorname{Marcos}^{99}$, donde todavía se conserva, aunque bastante deteriorada ${ }^{100}$. La escultura, plana por detrás por estar adosada al muro, representa al monarca ataviado con el Toisón de Oro; en la actualidad es de medio cuerpo y está formada por dos bloques, pero creemos que originalmente sería una representación de cuerpo entero, faltando por tanto la tercera pieza con las piernas, perdida seguramente en el desmontaje (fig. 8).

El Ayuntamiento decidió derribar el arco de la puerta en 1868. El acta municipal del 1 de febrero recoge el acuerdo, fundamentado en que no tiene mérito artístico que

\footnotetext{
98 QUADRADO, José María, (1885), op. cit., p. 369.

99 EGUIAGARAY PALLARÉS, José, León y la tragedia de D. Pedro Balanzátegui Altuna, León, 1969 , p. 89.

100 Aparece ya citada su procedencia en NIETO, Ángel, Guía histórico- descriptiva del Museo Arqueológico Provincial de León, Madrid, 1925, p. 57.
} 


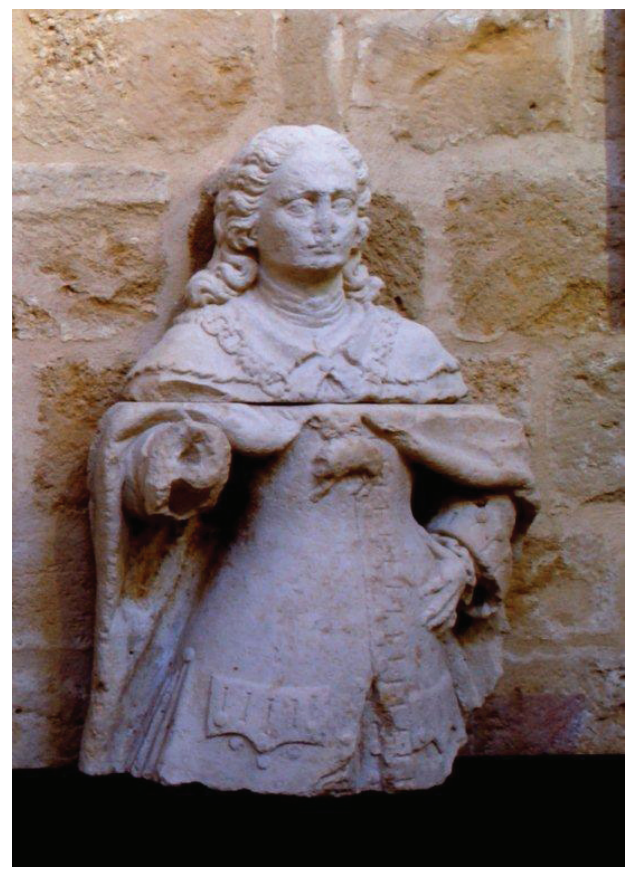

Fig. 8: Escultura de Carlos III que estaba en Puerta Moneda (Museo de León).

aconseje su conservación. También aduce que dificulta el tránsito por el lugar, por ser muy estrecha, e incluso es un inconveniente para la salud pública, pues impide la ventilación de la zona. A todo esto se une la posibilidad del posterior uso de los materiales del derribo en la construcción de un puente ${ }^{101}$. De esta manera se unen los principales argumentos que suelen justificar la mayoría de las demoliciones: el escaso valor estético, la higiene pública, la necesidad de mejorar la circulación de una ciudad en crecimiento y aprovechar sus materiales. En esta ocasión no se alude al estado ruinoso porque la estructura debía ser consistente, pues ya vimos que fue adecentada en 1840 cuando se abrió el paso tras la Guerra Carlista. El desmonte del arco ya estaba casi consumado al mes siguiente del acuerdo, ya que se autoriza la adjudicación en subasta pública de la obra necesaria para "completar el derribo"102, y pocos días después se fija un nuevo remate, esta vez para la extracción de los escombros resultantes ${ }^{103}$.

Uno de los estribos donde se apoyaba el arco se mantuvo en pie hasta 1870 , momento en el cual, a propuesta de la Comisión de Policía y del arquitecto municipal,

101 AHML, caja 95, n 151, fol. 12 r: Se acuerda que se derribe el Arco de Puerta Moneda por no tener objeto ni merito alguno y porque estrecha y dificulta el paso y ventilación, y que se aproveche sus materiales en el puentecillo que hay que construir en el camino de la Casa del Parque.

102 AHML, caja 95, n 151, fol. 16 r: Se acuerda que se complete el derrivo del Arco de Puerta Moneda, adjudicando la obra en subasta pública.

103 AHML, caja 95, n 151, fol. 27 v: Se acuerda que se subaste la extracción de los escombros de la muralla de Puerta Moneda. 
se autorizó su derribo. La obra correría por cuenta de un vecino, aunque con la obligación de dar al Ayuntamiento los sillares resultantes, a cambio de autorizarle a hacer un corredor en la muralla aledaña para uso particular ${ }^{104}$. En la actualidad es la única puerta de la cual quedan vestigios a la vista, aunque poco relevante para interpretar ni su estructura ni su apariencia original (fig. 6).

\subsection{Puerta San Francisco}

Llamada así por su proximidad al convento de san Francisco. También citada como Puerta Gallega, porque de aquí partía la carretera hacia Galicia. Su configuración ya la vimos al ponerla de ejemplo para las puertas medievales.

En la reunión municipal del 27 de noviembre de 1851 se vio un expediente del arquitecto que declaraba ruinoso al Arco de san Francisco. En el mismo acto se acordó demolerlo, adjudicando la ejecución de la obra a quien la verificase por menor suma bajo las condiciones propuestas por el arquitecto, presentando la documentación al Gobernador para que diera su conformidad ${ }^{105}$. El remate para la adjudicación de la obra se retrasó inexplicablemente, quizás por la intervención del Gobernador, pues no fue anunciado hasta marzo del año siguiente ${ }^{106}$. La obra de desmonte debió de empezar dos meses después, pues a finales de mayo el Ayuntamiento da cuenta del informe del arquitecto sobre la propuesta de un vecino que pedía dejar el soporte del arco que se estaba derribando, con el fin de que sirviera de apoyo a su casa. El arquitecto municipal accedió, demostrando una vez más la utilización de los muros defensivos como soporte para uso particular ${ }^{107}$. Los trabajos no fueron muy diligentes ya que en septiembre se previene al contratista para que termine el derribo antes de acabar el mes, porque en caso contrario lo tendría que hacer a su costa ${ }^{108}$. No obstante, ciertos problemas con los vecinos retrasarían el final de la puerta. A primeros de octubre el Ayuntamiento comunica, contestando un memorial presentado por un particular, que el contratista desmantelará todos los elementos de la puerta, sin excepciones. Suponemos que a partir de ese momento los trabajos terminarían pronto, ya que no hay nuevas referencias sobre el asunto en actas sucesivas ${ }^{109}$.

\footnotetext{
104 AHML, caja 95, n 152, fol. 21 r: Se acuerda autorizar a Marcos Álvarez para hacer un corredor sobre la muralla en Puerta Moneda con las condiciones que expresa el informe.

105 AHML, caja 93, n 142, fol. 71 r: Se vio una comunicación del Sr. Arquitecto en que se denuncia como ruinoso el Arco de San Francisco... y que para ello se eleve el expediente a la aprobación del Sr. Gobernador.

106 AHML, caja 93, n 143, fol. 28 r: ...un informe de la Sección de policía en que propone que se derrive el Arco de Santana ...y que se proceda al remate con arreglo a las condiciones fijadas por el Sr. Arquitecto.

107 AHML, caja 93, no 143, fol. 58 r y v: Se dio cuenta de un informe emitido por el Sr. Arquitecto sobre un memorial de Don José Rodríguez en que pide que se permita dejar dos o tres pies de muralla en el Arco de San Francisco que se está derrivando para que sirva dicha muralla de resguardo a una casa del exponente, ya que ningún perjuicio se sigue al público con esto.

108 AHML, caja 93, $\mathrm{n}^{\circ} 143$, fol. $85 \mathrm{v}$.

109 AHML, caja 93, n 143, fol. 86 r: ... se declara que el contratista del derrivo del Arco de San Francisco no está autorizado para dejar en pie parte alguna de la muralla de dicho arco...
} 


\subsection{Puerta Arco de Ánimas}

Era conocida con esta denominación porque estaba al lado del cementerio del Hospital de San Antonio Abad, además de ser el lugar por el que salían los entierros hacia el antiguo cementerio ubicado extramuros, que no quedaba lejos. También es citada en ocasiones como Puerta del Malvar, por conocerse popularmente de esta manera a los cementerios, donde se va a "criar malvas". Tampoco podemos olvidar que en sus cercanías tenía su sede la cofradía de las Ánimas de san Marcelo. Por su situación, era denominada en ocasiones Puerta del Hospital y también Puerta del Burgo Nuevo, atendiendo al arrabal surgido en la Edad Media al cual daba paso. A la vista del plano conservado parece que tenía un solo vano y estaba defendida por una torre de base cuadrangular.

La demolición de la puerta fue decidida en julio de 1851, cuando el arquitecto municipal presentó un expediente que declaraba al Arco de Ánimas en estado ruinoso. Aconsejaba derribarlo inmediatamente, tanto por su precaria estabilidad como por el desdoro para la ciudad, lo que nos hace suponer que estaría muy deteriorado. La misma opinión tenía la Comisión de policía que hizo un dictamen en términos parecidos. Ante la rotundidad de los informes, el Ayuntamiento aprobó sin más discusión el derribo, pasando la documentación al Gobernador para su sanción ${ }^{110}$. En el mismo acto se acordó sacar la obra a información pública y, para evitar gastos al erario público, se ofrecía adjudicar la obra a cuenta de los materiales resultantes del desmonte, utilizando así una fórmula habitual en la época y que se repite en actuaciones similares ${ }^{111}$. El derribo estuvo terminado en poco tiempo, pues a partir de septiembre del mismo año hubo una serie de reclamaciones ante el Ayuntamiento de afectados por la negligente manera de llevarlo a cabo, lo que había ocasionando importantes desperfectos en inmuebles contiguos. Entre ellos estaba el Hospital de san Antonio Abad, que presentó una protesta por daños en el edificio, quedando el contratista obligado a realizar la reparación por su cuenta ${ }^{112}$. También pidieron indemnización los propietarios de la casa que quedó en parte destruida al caer la estructura del arco, pero en este caso la Corporación municipal no atendió la reclamación porque adujo que los desperfectos habían surgido por estar la casa apoyada sin permiso en los soportes del arco, que no eran de su propiedad, sino pública ${ }^{113}$.

110 AHML, caja 93, no 142, fol. 44 r y v: Se leyó una denuncia hecha por el Sr. Arquitecto del Arco denominado de las Ánimas, en la que dice que tanto por el ornato público cuanto por el estado ruinoso de dicho arco, conviene derrivarlo... Se vio asimismo el informe emitido por la Sección de policía sobre este asunto en que opina como el Sr. Arquitecto, y se acuerda verificar el derrivo fijando edictos al público.

111 Una vez efectuado el derribo, en septiembre del mismo año, el rematante exige la entrega de las losas del arco que se le ofrecieron al hacer el contrato, cfr. AHML, caja 93, $\mathrm{n}^{\circ} 142$, fol. $61 \mathrm{r}$.

112 AHML, caja 93, n 142, fol. 59 v y 60 r: Se vio un informe emitido por el arquitecto sobre reclamación hecha por el administrador del Hospital.

113 AHML, caja 93, no 142, fol. 72 r: Se vio un informe del Sr. Arquitecto sobre un memorial presentado por D. Manuel Eustaquio Ramos y D. Marcelo Rodríguez para que se le refeccione la parte de casa que se les ha destruido al derrivar el Arco de las Ánimas, en cuyo informe se dice que ni el contratista ni el Ayuntamiento están obligados a tal refección porque la parte de casa maltratada sufrió desperfectos por hallarse construida sobre pared ajena, y se acuerda que no ha lugar a lo que se solicita. 
En 1856 todavía permanecía parte de uno de los machones del arco, pues los vecinos lindantes con la antigua puerta solicitaron al Ayuntamiento la cesión de dicha cepa para edificar y "hermosear" el sitio, petición que les fue concedida ${ }^{114}$.

La demolición no fue completa y suponemos que al menos alguna parte de la puerta debía quedar en pie en 1861, porque todavía había reclamaciones. La cuestión se plantea con una casa apoyada en la muralla, que ve peligrar su estabilidad cuando pretenden desmontar parte de esta y el propietario alega perjuicios graves para el equilibrio de su inmueble ${ }^{115}$.

\subsection{Puerta Santo Domingo}

Su denominación se debe a que estaba enfrente del convento de los dominicos, situado extramuros; su ubicación coincidía con la actual plaza de Santo Domingo. Fue conocida en algunas épocas como Puerta de San Miguel o también de Fajeros por el nombre de una calle aledaña. Quadrado, que al parecer la vio y la consideraba próxima a desaparecer, la otorga carácter monumental frente a las demás y la describe así: con su arco bajo de medio punto y sus bóvedas ojivales, más elevada la que mira al campo que la de dentro ${ }^{116}$, por lo que deducimos un pasaje amplio y armonioso, realizado con formas medievales. También sabemos, gracias a un suceso acaecido durante la Guerra Carlista, que la puerta estaba adornada exteriormente con escudos de armas flanqueados por estatuas, aunque desconocemos a quién pertenecían los blasones y cómo eran las esculturas que los custodiaban. El ingeniero director de las obras de fortificación de la ciudad de León en aquellos momentos cuenta que en la noche del 8 de junio de 1838 unos desconocidos, probablemente carlistas emboscados, dañaron dicho adorno a pedradas, además de provocar otros destrozos importantes en la misma zona ${ }^{117}$. Ignoramos el alcance real de los desperfectos, así como tampoco sabemos el destino final que tuvieron los relieves escultóricos reseñados.

El arco que cubría la puerta debía estar en mal estado a mediados del siglo XIX, ya que en febrero de 1856 el Ayuntamiento, tras conocer el dictamen de la Comisión de policía y la opinión del arquitecto municipal, propuso desmontarlo y hacer en su lugar otro más simple y funcional ${ }^{118}$. No obstante, la intención inicial se modificó porque pocos días después llegaba la autorización de la Diputación para proceder al derribo

114 AHML, caja 111, no 217, s/f, 15 de julio de 1856: Se vio el dictamen de la Comisión de policía sobre el expediente de cesión de la cepa del arco de las Ánimas para edificar y hermosear aquel sitio...

115 AHML, caja 94, $\mathrm{n}^{\circ}$ 148, fol. $42 \mathrm{v}$ : ...expediente de remate del terreno y materiales del antiguo arco de las Ánimas, y se oyó el informe verbal de la Comisión de policía en orden al memorial del rematante Sr. Balanzategui en que manifiesta que no puede continuar el derrivo por la oposición de D. Manuel Ramos, dueño de la parte de casa que se halla sobre el macizo que se ha de derrivar; y se acuerda que vuelva dicho expediente al Arquitecto para que midiendo el terreno diga si queda completo el espacio vendido sin tocar al mencionado macizo.

116 J. M. QUADRADO, (1885), op. cit., p. 369.

117 AHML, caja 716, n⿳⺈ 1, s/f, 22 de junio de 1838.

118 AHML, caja 111, $\mathrm{n}^{\circ}$ 217, s/f, 8 de febrero de 1856: Visto el dictamen de la Sección de Policía en que opina que conviene demoler el Arco de Santo Domingo, como propone el Arquitecto, ejecutando otro arco sencillo en su lugar, se acuerda como propone la Comisión y que se remita a la Diputación Provincial. 
total, ordenándose entonces hacerlo cuanto antes ${ }^{119}$. A principios del mes siguiente se acuerda verificar la demolición por subasta, quedando a beneficio del Ayuntamiento los materiales, obligándose el rematante a separar del escombro el material de piedra reutilizable y aprovecharlo para arreglar la deteriorada calzada de Santo Domingo ${ }^{120}$. En el contrato de la obra se fijaba el 31 de mayo como fecha límite para su conclusión ${ }^{121}$, pero a pocos días de cumplirse el plazo faltaba todavía mucho por hacer, lo que es aprovechado por el propietario del inmueble lindante con la puerta para solicitar que se dejara en pie el estribo derecho del arco. Argüía que él tenía el uso de esa parte de la muralla por haberla adquirido en su momento al Estado, viéndose perjudicado gravemente con el derribo ${ }^{122}$. La petición no debió de ser atendida ya que la demolición estaba terminada a finales de octubre. En ese mes el Ayuntamiento acordó pagar al contratista por su trabajo, tras comprobar que se habían cumplido las obligaciones estipuladas en el concurso ${ }^{123}$. Los restos del desmonte, como hemos visto en otros casos, fueron reutilizados; en esta ocasión el cabildo de San Isidoro los solicitó para emplearlos en la obra del atrio de la basílica ${ }^{124}$.

Los derribos dejaron a la vista unos restos poco decorosos, por lo que rápidamente se inició su arreglo para no deteriorar la imagen de la ciudad en una zona tan relevante para la nueva fisonomía que se pretendía conseguir de la capital. En este caso hubo serias discrepancias entre el Ayuntamiento, el contratista y los propietarios de las casas aledañas, que no se saldaron hasta varios años después, en junio de 1858 , con la obligación por parte de estos últimos de revocar y decorar las fachadas de sus propiedades, así como construir de inmediato en el espacio que había dejado libre la demolición de la puerta, que ellos habían comprado con la obligación de edificar cuanto antes para adecentar la zona ${ }^{125}$.

La desaparición de la puerta fue rematada años después con el desmantelamiento de la falsabraga que cerraba por el lado norte al hospital de san Antonio Abad. La obra fue aprobada en junio de 1863 alegando que así se logra dar ensanche a la en-

119 AHML, caja 111, n 217, s/f, 29 de febrero de 1856: Queda enterado el Ayuntamiento de la aprobación del expediente de derrivo del Arco de Santo Domingo dada por la Diputación, que pase a la Sección de Policía y Arquitecto para que propongan los medios de verificación del derrivo.

120 AHML, caja 111, n 217, s/f, 9 de marzo de 1856: Que el escombro se llevará a la plazuela del Rastro lo que se necesite para terraplenar los hoyos a la calzada de Santo Domingo.

121 AHML, caja 111, n 217, s/f, 27 de mayo de 1856: Concluyendo en 31 del corriente el término señalado para el derrivo y descombramiento del Arco de Santo Domingo y estando tan poco avanzada esta obra que si no se activan los trabajos llegará la fecha sin que se halle libre el paso...

122 AHML, caja 111, n' 217 , s/f, 28 de mayo de 1856: ...que tiene el uso de la muralla que adquirió del Estado a quien compró la casa, y a que se le irrogan grandes perjuicios con el derrivo de dicho Arco, se deje en pie el estribo de la derecha.

123 AHML, caja 111, n 217, s/f, 23 de octubre de 1856: Visto un oficio del contratista del Arco de Sto. Domingo que dice que están cumplidas todas las condiciones del remate... se acuerda que le paguen la cantidad acordada.

124 AHML, caja 94, n 146, fol. 5 r: Visto un memorial del cabildo de S. Isidoro en que pide la concesión de algunos sierros de los que pertenecen al Ayuntamiento y son procedentes del desmonte del Arco de Sto Domingo.

125 AHML, caja 94, no 146, fol. 50 r y 54 r y v: ... a la vista de una solicitud de D Francisco Iglesias, contratista del derrivo del Arco de Santo Domingo que se prevenga a la viuda de D Juan Antonio Nieto o a sus herederos que en todo lo que resta hasta $1^{\circ}$ de marzo de 1859 edifique en el sitio que ocupaba dicho arco que le fue vendido. 
trada más principal de la ciudad y hermosear uno de los puntos más concurridos de la población, como se argumentó en la reunión del Ayuntamiento en la que se decidió pedir permiso al Gobernador para llevar a cabo la demolición ${ }^{126}$. No debemos olvidar que la plaza de Santo Domingo era el punto donde confluía la nueva calle que llevaba a la reciente estación de ferrocarril con la principal vía del casco histórico, además de ser el inicio del Ensanche. La autorización para la demolición de la muralla fue concedida en agosto del mismo año ${ }^{127}$, completándose gracias al acuerdo conseguido con el cabildo de la catedral, del que dependía el referido hospital, para no perjudicar los intereses de esta institución ${ }^{128}$.

\subsection{Postigo del Oso}

Terminamos la relación de las demoliciones con este postigo, abierto probablemente a finales del siglo XIV en la antigua muralla romana para dar salida a la plazuela del Conde (donde está el palacio del Conde Luna) hacia la calle Azabachería, importante vía comercial del momento. Esta pequeña abertura, citada en la documentación como postigo estrecho y que ofrece fácil albergue a malhechores durante la noche ${ }^{129}$, era un lugar indigno en el centro de la ciudad. El Ayuntamiento admitió la proposición hecha en octubre de 1859 por Felipe Quirós, aceptando la cesión de la casa que este había comprado al Estado en las inmediaciones del postigo, con objeto de tirarla y ensanchar así el paso entre la plaza y la calle citada. La oferta, a cambio de ciertas prebendas para el propietario, fue aprobada a principios del año 1860, atendiendo a la mejora vial e higiénica que supondría para la ciudad ${ }^{130}$. En mayo se derribó la casa, aprovechando la ocasión para desmontar al mismo tiempo el cubo de la muralla romana al que estaba adosada, abriendo de esta manera un amplio paso al desaparecer un tramo considerable del primitivo lienzo defensivo romano ${ }^{131}$.

Nos sirve esta actuación como colofón que ejemplifica y resume el proceso destructor del recinto amurallado, pérdida patrimonial finisecular justificada con la excusa de la renovación urbana y la coartada de poner a León en siglo XX con la apariencia de una ciudad moderna ${ }^{132}$, aunque realizada de manera torpe, ya que, como

126 AHML, caja 95, n 149, 30 de junio de 1863, s/f

127 AHML, caja 94, n 149, 4 de agosto de 1863, s/f: Visto un oficio del Sr. Gobernador en que se autoriza al Ayuntamiento para proceder al derribo de la falsabraga sita al norte del Hospital.

128 AHML, caja 94, n 149, 16 de agosto de 1863, s/f: ...y convino dicho Cavildo en desistir de la oposición al prenotado derribo.

129 AHML, caja 94, no 147, fol. 192.

130 AHML, caja 94, n 147, fols. $4 \mathrm{r}$ y v: ...expediente instruido para la apertura de una calle desde la plazuela denominada del Conde a la calle de la Azavachería... y precisamente en el sitio que ocupa la casa de Felipe Quirós por ser este el punto más conveniente... que desaparecerá de esta ciudad el sitio más feo y sucio que actualmente tiene convirtiendola en una hermosa calle ventilada y desaogada.

131 AHML, caja 94, n 147, fols. 34 v y 35 r: ...se acuerda que se aumente la cantidad de tres mil reales a la que debe percibir Felipe Quirós, según convenio aprobado en consideración a que el derrivo del cubo practicado por este disminuye los gastos de demolición que la Municipalidad tendría que hacer.

132 Desaparecen en estas fechas, entre otras partes del recinto, el antiguo postigo de Renueva, la muralla de la subida a San Isidoro, los cubos del lienzo de la zona del Rastro o los de la calle Carreras. 
otras ocasiones, las obras dañaron edificios colindantes y los vecinos se quejaron por los desperfectos ocasionados ${ }^{133}$.

El derribo fue respaldado con las mismas razones vistas en casos similares: fin de la función militar, suprimir estructuras ruinosas, permitir la expansión de la ciudad, mejorar la comunicación interurbana, corregir condiciones higiénicas, incrementar la seguridad, reparar el desdoro urbano y otras similares; a las que nosotros añadimos el interés especulativo por liberar espacio para nuevas construcciones y revalorizar solares y edificios antiguos.

133 AHML, caja 94, no 147, fols. 76 v y 77 r: Visto un memorial de D. Juan Gorgojo insistiendo en que ha quedado su casa en muy mal estado por efecto del derrivo del arco conocido con el nombre de Postigo del Oso. 